\title{
Do National Policies Translate into Local Actions? Analyzing Coherence between Climate Change Adaptation Policies and Implications for Local Adaptation in Nepal
}

\author{
Kumar Bahadur Darjee ${ }^{1, *(\mathbb{D})}$, Ramesh Kumar Sunam ${ }^{2}$, Michael Köh1 ${ }^{1}$ (D) and Prem Raj Neupane ${ }^{1,3}$ \\ 1 World Forestry, University of Hamburg, Leuschner Strasse 91, D-21031 Hamburg, Germany; \\ michael.koehl@uni-hamburg.de (M.K.); prem.raj.neupane@uni-hamburg.de (P.R.N.) \\ 2 Waseda Institute for Advanced Study, Waseda University, 1-6-1 Nishi Waseda, Tokyo 169-8050, Japan; \\ sunam@aoni.waseda.jp \\ 3 Friends of Nature (FON), Kathmandu P.O. Box 23491, Nepal \\ * Correspondence: kumar.darjee@studium.uni-hamburg.de
}

\section{check for} updates

Citation: Darjee, K.B.; Sunam, R.K.; Köhl, M.; Neupane, P.R. Do National Policies Translate into Local Actions? Analyzing Coherence between Climate Change Adaptation Policies and Implications for Local Adaptation in Nepal. Sustainability 2021, 13, 13115. https://doi.org/ $10.3390 /$ su132313115

Academic Editor: Anastasios Michailidis

Received: 27 October 2021

Accepted: 23 November 2021

Published: 26 November 2021

Publisher's Note: MDPI stays neutral with regard to jurisdictional claims in published maps and institutional affiliations.

Copyright: (c) 2021 by the authors Licensee MDPI, Basel, Switzerland. This article is an open access article distributed under the terms and conditions of the Creative Commons Attribution (CC BY) license (https:// creativecommons.org/licenses/by/ $4.0 /)$.

\begin{abstract}
National climate change policy and strategies set out a framework for planning and undertaking climate change adaptation as well as mitigation activities at the national and local levels. In this article, we examine the coherence and contradictions between national policies and plans, and its impacts on the implementation of adaptation measures at the local level. We undertook a content review of key climate change policy documents $(n=4)$ of Nepal. In addition, we conducted a field study in the Rajdevi Community Forest User Group (CFUG) located in the mid-hills of Nepal, which has developed and implemented a community level adaptation plan of action (CAPA). The field study involved household interviews, focus group discussions, and an in-depth analysis of CAPA implementation. The paper found that while policies are coherent for targeting highly affected areas and communities, they deviate from discerning an appropriate planning and implanting unit. The local adaptation plan of action (LAPA) considers the local government as an implementing unit, while the national adaptation program of action (NAPA) puts an emphasis on the local community groups. It suggests that the existing LAPA implementation breaches the provision of community-level institutions for the implementation conceived in the central framework. Despite little attention to promoting food security in climate change policy, through the CAPA, local communities have planned and implemented adaptation measures envisioned in the thematic areas identified in the climate change policy of Nepal: agriculture and food security; forests and biodiversity; water resources and energy; climate-induced disasters; public health; and urban settlements and infrastructure. Nevertheless, the CAPA is not institutionalized under government policies and the institutional framework as a local level implementing unit. So, the consensus for a local implementing unit in the policies has remained a key issue. We suggest identifying a suitable and acceptable unit for implementing climate change adaptation at the community level. Only if an appropriate implementing unit is identified can the policies be successful with a broader acceptance and desirable outcomes enshrined in the climate change policy.
\end{abstract}

Keywords: climate change policy; adaptation; local adaptation; institutional framework; Nepal

\section{Introduction}

Climate change effects are widespread and alarming, and many of them are already generating negative impacts on human well-being [1]. Poverty, lack of access to health facilities and education opportunities, and deficiency of social safety nets exacerbate people's vulnerability to climate change $[2,3]$ in the least developed countries, including Nepal. Nepal's geology and ecological fragility, coupled with poor socio-economic condition, have made it one of the most vulnerable countries to climate change [4]. Dalit (a socially excluded community), indigenous peoples and local communities (DIPLCs) residing in 
geographically fragile mountainous areas are particularly vulnerable to climate change impacts in Nepal. Erratic rainfall, floods, prolonged droughts, landslide, and air and water-borne disease outbreaks have been the major climate-related disasters faced by the DIPLCs. The DIPLCs represent the economically and socially disadvantaged and are mostly thriving on marginal land for their livelihoods. They are being hit the hardest and disproportionately by the extreme events induced by climate change.

In Nepal, as in other countries, various climate change policies and strategies are in place to address climate change issue. They are informed by the United Nations Framework Convention on Climate Change 1992 (UNFCCC) [5], which is a global policy framework for climate change mitigation as well as adaptation, which sees governments as a principal actor at the national level [6]. Nepal's key climate change-related policies are the National Adaptation Program of Action (NAPA), Climate Change Policy 2019, the framework for Local Adaptation Plan of Action (LAPA), and Nationally Determined Contribution 2020 (NDC). The Government of Nepal (GoN) has prepared the NAPA, which was endorsed in 2010. The NAPA is a strategic tool to assess climate vulnerability and to address national adaptation priorities in a systematic manner. Climate Change Policy 2019 has provided multiple avenues for addressing the adverse impacts of climate change. The LAPA has been prepared to implement the NAPA and the Climate Change Policy, and to facilitate the climate change adaptation program at a local level.

Nepal was declared a federal republic in 2008 and is divided into seven provinces. As provisioned in Climate Change Policy 2019, the provincial government also started formulating the Provincial Adaptation Program of Action (PAPA) from 2019. As of 2021, more than 700 LAPAs have been developed and implemented across the country [7]. To implement LAPAs, the ward (the smallest unit of municipality or rural municipality of administrative divisions in Nepal), municipality, and rural municipality have been identified as operational entities. The LAPA preparation program is still ongoing in the remaining districts. In addition to LAPA, the concept and approach of the Community Level Adaptation Plan of Action (CAPA) has also been brought forward to develop and implement an adaptation plan at the community level [8]. Up to date, more than 2500 CAPAs have been prepared and implemented in Nepal [7]. Most CAPAs in the hilly regions of the country are prepared at the levels of Community Forest User Groups (CFUGs) and Farmer Groups. The CFUGs are considered relatively resourceful and successful grassroots institutions in the forestry sector and effective ways to reach climate vulnerable communities in Nepal [9].

The Government of Nepal has started the process of National Adaptation Plan (NAP) development since 2015 as a way to facilitate medium-to-long-term climate adaptation planning, building on the country's rich learnings from the implementation of NAPA and the previous Climate Change Policy of 2011. Nepal has formulated the Climate Change Policy 2019 [10] aiming at integrating climate change issues into policies and programs at all three tiers of government: federal, provincial, and local.

The successful implementation of policies to achieve desired objectives essentially expects policy coherence between different layers of the policies [11,12]. The policy coherence has received increased attention in recent days $[13,14]$. The concept of policy coherence in climate change and sustainable development has been a global concern. The formulation of national sustainable development strategies globally and the impact assessment procedure in the European Union [15] set an example of policy coherence. The coherent actions through mutually supportive policies are fundamental to the Sustainable Development Goals (SDGs) [16,17], and SDG 13 in particular highlights it for climatic issue. The UNFCCC, including the NDCs, should provide assurance of policy coherence across different sectors for effectively and efficiently addressing climate change challenges in line with the Paris Agreement [16,18]. The Framework for Disaster Risk Reduction 2015-2030 has also prioritized policy coherence [19]. Policy coherence deals with consistency and compatibility across different governance layers throughout the complete policy cycle, from policy objectives to impacts in order to promote synergies [15]. Policy coherence increases policy stability and decreases the chances of policy failure [20]. The poor policy 
coherence primarily causes coordination and implementation difficulties, leading toward an inefficient use of available resources [21,22]. So, policy coherence is required for a logical consistency throughout all dimensions of policy development and implementation process. The Organization for Economic Co-operation and Development (OECD) highlights that policy coherence is essential for the transformation of systems that undermine people well-being, structural inequalities, and enduring vulnerabilities [23]. It can help build resilience and bring necessary changes in the ways of economic use of resources (natural, economic, human, and social), leading to harnessing synergies and trade-offs while avoiding or reducing negative impacts of policies [23].

It can be inferred that when national policies are not translated into local actions, the desired outcomes cannot be achieved, making climate vulnerable people likely to face exacerbating impacts. A number of barriers hinder policies and plans to be translated into local actions. The major obstacles include inadequate national capacities to implement policies, a bunch of plans without securing necessary resources, lack of piloting, confusion due to lack of policy coordination and overlapping mandates, conflicting interests of stakeholders, political interference, and fragmentation and undermining of country-led processes due to incautious donor initiatives [24].

Given the number of climate change policies and adaptation strategies that have been developed and adopted for more than a decade at national, provincial, and local levels in Nepal, the question arises to what extent these policies are coherent and contradictory between themselves. Given the proliferation of policies, their implementation and impacts need to be analyzed from a coherent perspective. There have been very few studies in this direction in Nepal. In this backdrop, this paper investigates the implications of climate change policy's coherence and gaps between them to understand the translation of policy provisions into local level implementation.

Existing research on climate change adaptation and policy has predominantly focused on policy formulation process, climate vulnerability, impacts on peoples' livelihoods and community adaptation; few examine policy coherence. Ranabhat et al. [25] analyzed sectoral policy coherence between climate change policy and forest policy. Gentle and Maraseni [26] examined weather patterns and challenges associated with different aspects of the peoples' livelihoods including resource degradation, food scarcity, and increasing social inequalities. Dulal et al. [27] explored the ability of poor communities to adapt to climate change impacts, highlighting a knowledge gap to implement the policies, insufficient literacy, continuation of natural resource depletion, land and livestock ownership, and inadequate access to financial services. Jones and Boyd [28] explained the social barriers for adaptation action and adaptive capacity. They analyzed cognitive behavior, normative behavior, and institutional structure and governance, which play a vital role in allowing and/or avoiding successful and rational adaptation. Sapkota et al. [29] analyzed the importance of overcoming the socio-cultural drivers of marginalization in the spectrum of socio-economic heterogeneity at a wider societal level to work effectively for the marginalized groups. They highlighted the need for social inclusion by addressing intra-community distribution of vulnerability. Maharjan et al. [30] studied the indigenous skill and adaptation of Tharu, an indigenous community living in Terai, a low-land region of Nepal. They found that the indigenous community faced climatic stresses every year and used their traditional skills and experiences for building their adaptive capacity. Regmi and Bhandari [31] showed that the climate change policy of Nepal lacks clarity and policy visioning for the advancement of climate change adaptation. They analyzed barriers in designing and implementing climate change policy focusing on institution, technology, and information. Eriksen et al. [32] argued that adaptation needs to be reframed as a socio-political process interacting between authority, knowledge, and subjectivities across scales by multiple actors. Ojha et al. [33] explored the politics for climate policy development in Nepal examining the context of an international aid and demand for inclusive public processes. They depicted how a technocratic framing of climate change vulnerability and adaptation reinforced the design of the NAPA and other climate policies. Silwal et al. [34] analyzed 
the adaptation planning process in forest-based communities in Nepal. Paudel et al. [35] highlighted the advantage of marginalized communities in planning and implementation of adaptation actions. Aryal et al. [36] found that environmental policy making in Nepal is government monolithic and expert-based. While these existing studies have focused on diverse aspects of climate change, there remains little research on policy coherence, which we attempt to consider in this paper.

\section{Policy Coherence: Definitions and Analytical Frameworks}

While there is no universally agreed definition of policy coherence, it is widely conceived to contribute to policy stability and reduce policy failure [20]. Policy coherence is synonymous with various ideas and terms including coherent policy making, policy co-ordination, policy integration, holistic government, and joined-up government coherence [37]. For example, policies are integrated when their objectives, goals, actors, procedures, and instruments (organizations and administrative procedures) are explicitly adjoined [14]. Challis et al. [38] broadly classify policy co-ordination as "a pursuit of coherence, consistency, comprehensiveness and of harmonious compatible outcomes". The Organization of Economic Cooperation and Development, Development Assistance Committee (OECD-DAC) defines policy coherence as "the systematic promotion of mutually reinforcing policies across government departments and agencies creating synergies towards achieving the defined objective" [39]. The OECD's consideration of policy coherence gives emphasis on the policy-making process and identification of criteria including stakeholder involvement, knowledge management, and commitment and leadership [40]. The North-South Institute (NSI) in Canada defines policy coherence as "ensuring policies are coordinated and complementary or at least not contradictory" [41]. It is "an attribute of policy that systematically reduces conflicts and promotes synergies between and within different policy areas to achieve the outcomes associated with jointly agreed policy objectives" [15] (p. 396). May et al. [42] define that "policy coherence is a relative term that relates to the degree of integration of relevant components (of a policy)". The coherence explains policies that fit together for both an outcome and a process [43], referring to relationships between different tiers of policies [15]. Primarily policy coherence focuses on policy output including objectives, design, and instruments to implement at various levels $[44,45]$. Policy coherence is largely expected to minimize conflicts and disagreements promoting synergies between and within distinct policies [46]. It fosters better efficiency by reducing competition for the same available resources [47]. Whilst there is a mounting importance of policy coherence, identifying the presence and degree of policy incoherence is equally important to figure out the presence of problems. Hoebink [48] suggested that policy incoherence is not only guided by political, administrative, and institutional reasons but also by cognitive reasons. This indicates the fact that insufficient knowledge pertaining to the effects of policy decisions and disagreeing legitimate interests lead to policy incoherence [49]. In the context of climate change policies and strategies of Nepal, it can be argued that those policies are struggling to achieve stated goals. There is a paucity of research on whether there is informed decision-making practice and actions/activities representing legitimate interests of the local communities. Similarly, there is still little effort being made to find coherence between climate change policies. So, this study on these issues of Nepal is expected to be helpful in enhancing institutional synergy in the implementation of adaptation measures at a local level.

Different conceptual frameworks have been developed to measure the degree of policy coherence such as policy integration, policy interaction, or policy consistency [13]. Briassoulis [50] suggested that policy integration can be assessed vertically (across organizational levels) and/or horizontally (along the same levels).Vertical policy coherence refers to "coherence between different levels of government" [37], while horizontal policy coherence refers to "coherence between policy areas at one level" [15]. Duraiappah and Bhardwaj [14] explained that horizontal coherence involves coherence among policies at each level (international, national, and local) before the implementation of actions and ver- 
tical coherence integrates coherence between instruments, institutions and organizations. Meuleman [51] considers that the horizontal coherence requires overcoming silo thinking. He identifies that the vertical coherence is fundamental to anchor alignment, collaboration, and development that includes civil society, the private sector, and development institutions in order to provide input in policy development, facilitation, support, finance, and implementation. Policy coherence analysis tends to focus on both procedural aspects of the policy-making process $[40,52]$ and output assessment of the policy $[13,15,53,54]$, which can be carried out at three levels: policy objectives, policy instruments, and implementation practices [15]. Duraiappah and Bhardwaj [14] suggest that policy coherence can be analyzed in terms of goals (overall themes), instruments and decisions (ways to achieve the goals), and actors (institutions responsible) to achieve. A similar analytical framework has also been proposed by Nilsson et al. [15] that entails policy objectives, policy instruments, and policy implementation. Our study mostly follows the latter two policy-analytical approaches for policy coherence analysis. As suggested by Browne [55], the coherence of a policy aspects depends on how issues and their interests relate each other.

Building on these definitions and analytical frameworks, the study focuses on vertical coherence of climate change adaptation policies in regard to three policy dimensions: policy goals, provisions, and implementing actors at a local level. In doing so, we analyze the coherent characters of central, provincial, and local polices/plans, and major gaps between them, highlighting the consequences to the local-level implementation of adaptation measures. The policy analysis includes the analysis of major climate change adaptation policies, i.e., Climate Change Policy 2019 and NAPA; the provincial policy covers the PAPA and local policies consider the LAPA. The implementation of adaptation measures is drawn from the case study of the CAPA developed and implemented by the CFUG in the mid-hills of Nepal linking to the thematic areas of climate change policies and adaptation framework of Nepal. As mentioned in NSI's definition, the complementary of the policies as the assurance of coherence [41], this study also highlights the CFUG's practices that are congruent to the objectives of climate change policies. Fiske [56] also explains complementarity as the respective actions of the participants cooperating with each other and benefitting mutually by shared coordination devices and understanding.

This study comprises three research questions. (i) How coherent are the climate change policies: Climate Change Policy 2019, NAPA, PAPA, and LAPA? (ii) To what extent are the policy's provisions / prioritization reflected in the local adaptation plan, and how do the community's practices complement the climate change policies and strategies? (iii) What are critical gaps between policies and local adaptation actions enshrined in CAPAs?

Policy coherence considers policy focus (goal/objectives), instruments (institutional decision, provision), and actors for planning and implementation. The reflection of policy provisions at the local level explains the communal as well as individual adaptation activities of CAPA linking to the thematic areas of Climate Change Policy 2019. The complementary measures explain the community's practices that have been already initiated at the local level and are corresponding to the Climate Change Policy's aspirations. Finally, analyzing critical gaps highlights institutional involvement; the capacity building of stakeholders who are being closely worked with; and the local level implementing unit.

As adaptation programs emphasize the need for addressing local requirements and these essentially need to be implemented and managed locally $[57,58]$, this study considers the CFUG having the CAPA as an implementing unit of local adaptation actions. Khatri et al. [59] outlined the major six types of local groups engaged in natural resource management and community development in Nepal: CFUGs, Water User Groups, Agriculture Groups, Livestock-Based Group, Saving and Credit Cooperatives, and Women Groups, emphasizing the CFUG having a prominent institutional setup for adaptation planning. The findings from analyzing the content and contention between climate change policies, strategies, and local practices could be utilized by policy makers, service delivery agents, implementers, and those engaged in climate change adaptation to inform their works for better policies and strategies. 


\section{Materials and Methods}

\subsection{Study Area}

Fieldwork for collecting empirical data was conducted in Rajdevi CFUG of the Gorkha district, which is located in the mid-hill region of Nepal (Figure 1). Based on the IPCC vulnerability index (i.e., very highly vulnerable, highly vulnerable, medium vulnerable, and low vulnerable) [60], the Gorkha district falls under the highly vulnerable category [61].

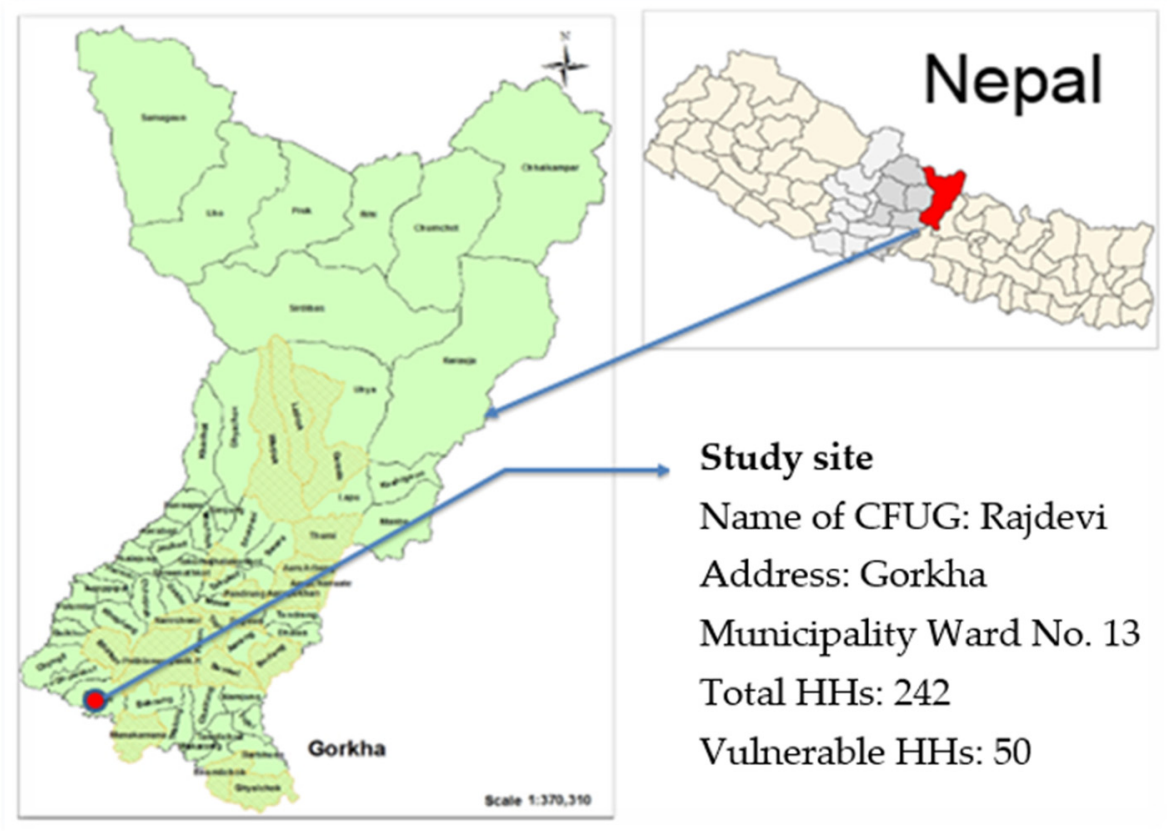

Figure 1. Map of Nepal showing study area Gorkha district, located in the central Nepal in the Middle-Mountain zone.

The Rajdevi CFUG was selected for several reasons. First, the NAPA 2010 and the first Climate Change Policy 2011 provisioned local communities as implementing units for climate change adaptation program. Under this provision, the CFUG has prepared a CAPA that has been implemented for over five years. Second, the CFUG lies in a vulnerable geographical area experiencing extreme climate vulnerability, facing climateinduced hazards such as landslides, droughts, and water deficiency. The heterogeneity of CFUGs in relation to caste, ethnicity, and well-being of users was also one of the main reasons for the selection of this CFUG. The CFUG is comprised of a total of 242 households representing diverse caste, ethnicity, and economic status. Out of the total households, 50 households fall under the vulnerable category (very highly vulnerable 20, and highly vulnerable 30), 123 are moderately vulnerable, and 69 are in the group of low vulnerability. Out of the 50 vulnerable households, 37 households belong to indigenous peoples.

\subsection{Data Collection Tools and Analysis}

This study used a mixed methods research approach. Both qualitative and quantitative data were collected using a range of research methods namely household (HH) surveys, focused group discussions (FGDs), expert interviews, and interviews with key informants (KI). For policy analysis, a rigorous document review was conducted. Table 1 below presents methods used for data collection and details of the respondents. 
Table 1. Types of respondent and data collection tools used.

\begin{tabular}{|c|c|c|c|c|c|}
\hline S.N. & Data Collection Tools & Events (No) & Participants (No) & Men (No) & Women (No) \\
\hline 1 & $\begin{array}{c}\text { Household survey } \\
\text { (semi-structured interviews) }\end{array}$ & 61 & $61(25 \%) *$ & 38 & 23 \\
\hline 2 & Focus group discussions & 4 & $109(45 \%) *$ & 58 & 51 \\
\hline 3 & Key informant interviews & 11 & 11 & 7 & 4 \\
\hline 4 & Expert interviews & 17 & 17 & 15 & 2 \\
\hline
\end{tabular}

A semi-structured questionnaire was used for household surveys. Few predetermined and open-ended questions were asked focusing on whether households have observed impacts of climate change and how they have grappled them. Particularly, the semi-structured interviews were emphasized to explore local adaptation measures after the community developed and implemented the CAPA. To triangulate the responses obtained from the interviews, FGDs and KIs were conducted. The KIs were consulted about policy coherence, too. The respondent's diversity was maintained by involving women, indigenous peoples, poor households, and climate-vulnerable people to represent the experiences of local impacts and adaptation measures.

Semi-structured interviews with HHs covered $25 \%$ of the total households within the CFUG: 61 out of 242 households. Since the study was focused at local adaptation practices to understand and explore the impacts of climate change adaptation interventions to the vulnerable group, most of the houses were interviewed from "very highly" and "highly" vulnerable communities (46 out of 50) (Table 2). This study followed a stratified random sampling for $\mathrm{HH}$ survey and purposive sampling for FGDs considering different vulnerability status of community. For expert interviews and KIs, the snowball method was used.

Table 2. Types of household respondents $(n=61)$ according to the IPCC vulnerability index.

\begin{tabular}{|c|c|c|c|c|}
\hline \multirow{2}{*}{ S.N. } & \multirow{2}{*}{ Vulnerability } & \multicolumn{2}{|c|}{ No of HHs } & \multirow{2}{*}{ Total } \\
\hline & & Men & Women & \\
\hline 1 & Very high & 9 & 11 & 20 \\
\hline 2 & High & 22 & 4 & 26 \\
\hline 3 & Moderate & 3 & 4 & 7 \\
\hline 4 & Low & 4 & 4 & 8 \\
\hline \multicolumn{2}{|c|}{ Total } & $38(62 \%)$ & $23(38 \%)$ & 61 \\
\hline
\end{tabular}

This study carried out four FGDs with the participation of 109 individuals (one moderate and low vulnerable group; one women group; one CFUG executive members; and one very highly vulnerable group). Discussions were open; however, the checklists have been used to lead the participants toward the main focus of the study. More than half of the total participants were women. In the FGDs, school teachers and local political leaders also participated and expressed their views. FGDs were very helpful to understand the views of the respondents belonging to different sections of the society, and representing different interest groups and well-being categories.

Altogether, 17 experts and eleven key informants (KIs) were interviewed with individuals with different designations and responsibilities in various levels from policy makers to implementers at the ground level (Table 3).

Six experts from the Ministry of Forest and Environment (MoFE), Department of Forest and Soil Conservation (DoFSC), andREDD Implementation Centre were consulted to gain insights about the policy process, coherence, strengths, and gaps. Similarly, eleven experts were interviewed from the climate change adaptation projects, international non-governmental organizations (INGOs), and national non-governmental organizations (NGOs) to acquire information about contribution of the climate change adaptation interventions to enhance local adaptive capacity. Furthermore, eleven KI from the Fed- 
eration of Community Forestry Users Nepal (FECOFUN), ex-chairperson of CFUG, local climate change facilitators, health technicians, and local entrepreneurs were also the source of information.

Table 3. Number of experts and key informants and their organizations affiliated.

\begin{tabular}{cccc}
\hline SN & Organizations & Number & Remarks \\
\hline 1 & Ministry of Forest and Environment (MoFE) (Then) & 3 & Experts \\
2 & Department of Forest and Soil Conservation (DoFSC) & 2 & Experts \\
3 & REDD Implementation Centre & 1 & Experts \\
& Climate change adaptation projects, international & & \multirow{2}{*}{ Experts } \\
4 & non-governmental organizations (INGOs) and national & 11 & \\
& non-governmental organizations (NGOs) & & Key informants \\
5 & Federation of Community Forestry Users Nepal & 4 & Key informants \\
6 & (FECOFUN), ex-chairperson of CFUG & 2 & Key informants \\
7 & Local climate change facilitators & 2 & Key informants \\
\hline
\end{tabular}

The contents and plans of CAPA were reviewed, and its implementation status was analyzed. We reviewed major policy documents including Climate Change Policy 2019 (central level policy), NAPA (central-level framework), PAPA (provincial-level framework), and LAPA (local-level framework). The data collected from the HH survey were analyzed using the Statistical Package for Social Science (SPSS) software and Microsoft excel. The HH surveys and FGDs at the community level were accomplished in 2017 just after the CFUG completed the five-year of CAPA implementation. Experts and KIs were interviewed in 2020. Climate change related policies published until 2019 were analyzed.

\section{Results}

\subsection{Content and Coherence of Climate Change Policies and Strategies of Nepal}

The Government of Nepal (GoN) started addressing climate change issues in 2010 with the formulation and implementation of NAPA 2010 followed by the Climate Change Policy 2011 and the Framework on Local Adaptation Plans for Action (LAPA framework 2011) of Nepal. Nepal was declared a federal republic in 2008 and is divided into seven provinces. From 2019, the Provincial Government also started the formulation of PAPA. CAPA was initiated informally in 2009 with the help of some development organizations (based on experts involved since the beginning of CAPA development and implementation) before formal policy instruments came into force. Although these policy strategies have contained their own objectives, institutional arrangement, and operational modality, they exhibit coherent attributes (see Table 4). 
Table 4. Holistic analyses of climate change policy's focus, provision, and implementing actors.

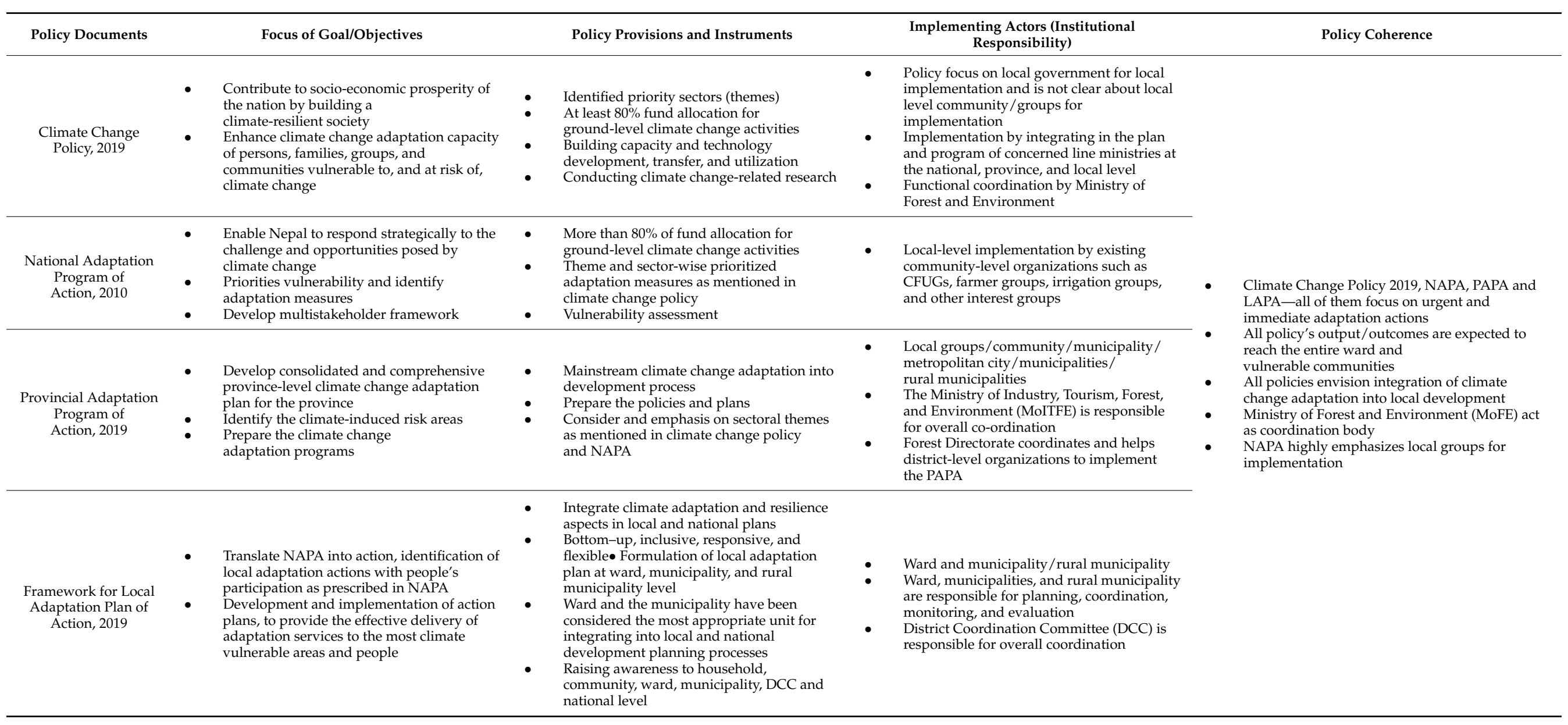




\subsubsection{Focus of Climate Policies and Strategies}

As pointed out in Table 4, the Climate Change Policy 2019 aims at improving livelihoods by mitigating and adapting to the adverse impacts of climate change, and by adopting a low-carbon emissions socio-economic development path [62]. Strengthening the institutional and financial systems of climate-affected people to make climate change responses more effective and efficient is also a major thrust of the climate change policy. The policy focuses on the socio-economic prosperity of the nation by building a climateresilient society and enhancing the adaptive capacities of individuals, major groups, and communities. This policy has set clear goals and targets to address climate change risk and vulnerability. The policy emphasizes the constitutional commitment of Nepal, assuring the fundamental right of every citizen to live in a clean and healthy environment. It considers an integrated climate change management concept in the backdrop of the federal system at all three levels-federal, provincial, and local government, thereby contributing to the vision of "Prosperous Nepal, Happy Nepali" adopted by the Government of Nepal [10] (p. 5). The policy also bolsters Nepal's commitment to national and international agreements related and relevant to climate change.

The NAPA was developed for urgent and immediate adaptation actions by identifying priority activities for climate change adaptation (see Table 4). The major focus of the NAPA is to enable Nepal to respond strategically to the challenge and opportunities posed by climate change by developing a multistakeholder framework for assessing vulnerability and identifying adaptation measures. As per the provision of climate change policy, the provincial governments have started a PAPA preparation. The Gandaki Province has come up with a final draft of this document which was formulated following the content and process of NAPA. The major focus of the PAPA is to develop a consolidated and comprehensive climate change adaptation plan for the province. Identifications of the climate-induced risk areas and preparing adaptation program accordingly has been descried in the PAPA.

The LAPA framework was first developed in 2011 to facilitate the implementation of climate adaptation programs at the local level. The Village Development Committee (previous structure of local government, the lowest administration unit of Nepal), municipality, and rural municipality-level LAPA preparation started and was implemented. Recently, the LAPA framework has been revised as Nepal transformed into federal and provincial administrative systems. This framework committed to translating the policy's priorities of climate adaptation into action, identifying local adaptation actions with people's participation as prescribed in NAPA, and providing the effective delivery of adaptation services to the most climate-vulnerable areas and people. As provisioned in the Climate Change Policy and NAPA, CAPAs have also been developed and implemented at various community levels, including CFUGs.

\subsubsection{Provisions and Instruments in the Policies}

A major climate change policy provision includes the decentralization of financial resources for climate change and the channeling of over $80 \%$ of the total climate budget directly to the grassroots level for implementing climate change adaptation activities. This provision has been re-emphasized in the NAPA, too. Conducting climate change research, technology development and transfer, and building the capacity of stakeholders are also included in the policy. The Climate Change Policy 2019 has prioritized seven different thematic and five inter-thematic areas. Thematic areas include agriculture and food security; forest, biodiversity, and watershed conservation; water resources and energy; rural and urban habitats; industry, transport and physical infrastructure; tourism and natural and cultural heritage; health, drinking water, and sanitation; and disaster risk reduction and management. Inter-thematic areas involve gender equality and social inclusion; livelihoods and good governance; awareness raising and capacity development; research, technology development, and expansion; and climate finance management. The NAPA 2010 clustered priority activities into six thematic areas: agriculture and food security; forests and 
biodiversity; water resources and energy; climate-induced disasters; public health; and urban settlements and infrastructure. PAPA has aligned in a way of mainstreaming climate change adaptation into the development process and preparing provincial-level policies and plans for climate change adaptation. PAPA has also emphasized sectoral themes as mentioned in the Climate Change Policy and NAPA.

The LAPA framework defines the process of formulating a local adaptation plan at ward, municipality, and rural municipality levels and considered the most appropriate unit for integrating them into local and national development planning processes. Raising awareness at household, community, ward, municipality, DCC, and national-level stakeholders has also been provisioned in the LAPA framework.

\subsubsection{Institutional Structure for Policy Implementation \\ Central Level Institutions}

The Government of Nepal has established the Climate Change Council (CCC) chaired by the Prime Minister for high-level political support. A Multi-Stakeholder Climate Change Initiatives Coordination Committee (MCCICC) was formed in 2009. In 2010, the GoN established the Climate Change Management Division (CCMD) under the then-Ministry of Population and Environment (then MoPE) and the REDD Forest and Climate Change Cell (now REDD Implementation Centre) under the Ministry of Forest and Environment (then MoFSC). While in the transformation of the unitary to federal system, two ministries-namely, the Ministry of Environment and the Ministry of Forests and Soil conservation-were merged into one and named as the Ministry of Forests and Environment (MoFE). CCMD under the MoFE is dedicated to climate change management. Furthermore, climate change management has been streamlined through the establishment of MoITFE in all of the seven provinces of the country. The CCMD coordinates with the provincial MoITFE. All of the coordination and leading tasks of the previous Ministry of Environment have been shifted to CCMD under MoFE. NAPA implementation is also coordinated by this division. This institutional framework has been considered effective for the planning and implementation of a climate change adaptation program to reduce the climate risk vulnerability of the local communities [63-65].

\section{Provincial-Level Institutions}

The Gandaki Province has finalized a PAPA. The MoITFE of the province is responsible for the overall co-ordination between line ministries and other respective bodies [66]. The MoITFE prepares policies and plans with the help of other implementing bodies and stakeholders. The Forest Directorate (FD) takes a responsibility as a connecting body between MoITFE and district-level organizations for the PAPA implementation. The FD is a provincial office to coordinate and monitor the Division Forest Offices (DFOs) and Soil and Watershed Management Offices (SWMOs), thereby helping the district-level organizations to implement the PAPA.

\section{District Level/Local-Level Institutions}

The LAPA framework facilitates a formulation of a local adaptation plan at the local level: ward, rural municipality, and municipality. At the district level, DCC plays a key role in coordinating climate change initiatives. As the LAPA framework considers the ward, municipality, and rural municipality as the most appropriate local implementing units [67], LAPA is prepared based on the prioritized need of local communities and forwarded to DCC for approval. For sectoral plans, district line agencies plan and implement adaptation activities. At a community level, various projects and government institutions have implemented adaptation interventions at different levels to capacitate the local communities and institutions to cope with climate change impacts. Development partners are using different local/community organizations as per their convenience since the government has not recommended an appropriate institution at a local level as an entry point for cli- 
mate change interventions. Table 5 shows various local groups involved in climate change adaptation programs.

Table 5. Principal institutions mobilized at a different level by various projects/organizations.

\begin{tabular}{|c|c|c|}
\hline Principal Institutional Mechanisms & Level & Project/Organization \\
\hline $\begin{array}{l}\text { Village Forest Coordination Committee (VFCC), } \\
\text { Agriculture Forest and Environment Coordination } \\
\text { Committee (AEFCC) }\end{array}$ & LAPA & \multirow{2}{*}{$\begin{array}{l}\text { Livelihoods \& Forestry Program/ Department for International } \\
\text { Development (LFP/DFID) and Interim Forestry } \\
\text { Project/Multi-stakeholder Forestry Program (FP/MSFP): from } 2011 \\
\text { to } 2016\end{array}$} \\
\hline CFUGs and public land management groups & CAPA & \\
\hline $\begin{array}{l}\text { Village Energy Environment and Climate Change } \\
\text { Coordination Committee (VEECCCC) }\end{array}$ & LAPA & $\begin{array}{c}\text { Nepal Climate Change Support Program/Government of Nepal } \\
\text { (NCCSP/GON-European Union/Department for International } \\
\text { Development (EU/DFID) }\end{array}$ \\
\hline CFUGs & CAPA & $\begin{array}{c}\text { Hariyo Ban Program/ United States Agency for International } \\
\text { Development (USAID) Nepal }\end{array}$ \\
\hline Village Climate Change Coordination Committee (VC4) & LAPA & \multirow{3}{*}{ Initiative for Climate Change Adaptation/(ICCA/USAID) } \\
\hline VFCC & LAPA & \\
\hline CFUG and Farmers Group (FG) & CAPA & \\
\hline VC4 & LAPA & \multirow{2}{*}{$\begin{array}{l}\text { Creating Community Climate Change Capacity (5C/Adventist } \\
\text { Development and Relief Agency-ADRA-Australia and Rupantaran Nepal) }\end{array}$} \\
\hline Cooperatives & CAPA & \\
\hline CFUGs and groups of poor and vulnerable communities & CAPA & CARE Nepal \\
\hline Source: $[68,69]$ & & \\
\hline
\end{tabular}

Field research showed that in order to coordinate household and community-level climate change adaptation activities, CFUGs are mobilized as grassroots-level community groups. It shows that CFUGs play a complementary role to implement polices at the local level. The Village Coordination Committees were formed at the local level as per the demand and convenience by funding organizations; these were chaired by the VDC (previous structure, now it is called a ward) secretary including delegates from all the CFUGs in the ward, political parties, government service providers, and existing local NGOs. This indicates that diverse community institutions have played an important role in the local-level implementation of the climate change adaptation program, thereby ensuring the participation, coordination, and cooperation of local-level institutions, organizations, private sectors, academics, and development partners, in a way suggested by Duraiappah and Bhardwaj [14], and Meuleman [51] in the framework of vertical coherence analysis.

\subsubsection{Coherence between Climate Change Policy, NAPA, PAPA, and LAPA}

Our review of Climate Change Policy, NAPA, PAPA, and LAPA shows that the major coherence between them is to target immediate and urgent adaptation measures and reach the local vulnerable communities. An integration of climate issues into the local development process is enshrined in all the policy instruments. The NAPA 2010 emphasizes local groups for implementation, and the Climate Change Policy considers the importance of indigenous knowledge, skills, and technologies by identifying climate change-affected households, communities, and risk zones. The overall coordination is mostly dominated by MoFE. The consistency of these policies instruments to their objectives focusing on the same targeted vulnerable populations and locations sets an example of policy coherence, and this is one of the essential components of vertical coherence analysis defined by Duraiappah and Bhardwaj [14] and Nilsson et al. [15].

\subsection{Reflection of Climate Change Policies' Provisions in Local Adaptation Actions and Complimentary Community Practices}

As depicted in Table 5, there are various institutions and implementing units of the climate change adaptation program in Nepal. Primarily, the adaptation program has been implemented at ward, rural municipality/rural municipality, and community levels. We 
assessed the community level adaptation plan and program, a CAPA linking to Climate Change Policy priorities and provisions. We highlight major climate change impacts experienced by community people and adaptation activities carried out by a CFUG.

\subsubsection{Assessing Climate Vulnerability and Local Impacts}

Interviews with local residents along with FGDs as well as in-depth analysis of CAPA showed that CAPA has been prepared following rigorous processes recommended by the LAPA framework. The process includes awareness creation, capacity building, vulnerability assessment and mapping, and adaptation plan preparation and implementation. The local people in Rajdevi CFUG experienced an increase in temperature. They have been experiencing erratic rainfall during crop cultivating and growing seasons. Local people perceived that the changes in these two major climatic parameters resulted in diverse consequences on their livelihoods. They identified different levels of climate change impacts in agriculture, land degradation including landslides/erosion, water deficiency, and fodder scarcity for cattle (see Table 6).

Table 6. Impacts and the scale faced by different categories of vulnerable people (percentage in parenthesis indicates the percentage of total interviewees). The vulnerable categories are defined in IPCC (2014): very high, high, medium, and low.

\begin{tabular}{ccccc}
\hline Impacts & Agriculture Crops Loss & Landslide/Erosion & Water Deficiency & Fodder Scarcity \\
\hline Very high & $9(15 \%)$ & $5(8 \%)$ & $47(77 \%)$ & $0(0 \%)$ \\
High & $39(64 \%)$ & $8(13 \%)$ & $11(18 \%)$ & $3(5 \%)$ \\
Medium & $12(20 \%)$ & $34(55 \%)$ & $3(5 \%)$ & $12(20 \%)$ \\
Low & $1(2 \%)$ & $14(23 \%)$ & $0(0 \%)$ & $46(75 \%)$ \\
\hline
\end{tabular}

The community has been facing diverse impacts of climate change such as crop failure, declining crop productivity due to drought, pest, and diseases, declining health, and the depletion of water resources. The local people expressed water deficiency as the topmost impact (very high impacts) posed by climate change in the area. Seventy-seven percent of the interviewees responded that they faced a drinking water deficit as a prime problem followed by agriculture crop lost (high impact) due to uncertain rainfall patterns and increased drought intensity (64\%). Meanwhile, 55\% of interviewees were impacted from landslide and erosion (medium impact) due to heavy rainfall that has caused the destruction of agricultural land and river-triggered erosion caused by swollen stream. A large segment of the respondents $(75 \%)$ raised the issue of increasing fodder scarcity because of a reduced trend of agriculture practice, degrading the quality and quantity of fodder species; however, this was considered low impact.

\subsubsection{Responding to Locally Identified Impacts}

Rajdevi CFUG adopted diverse adaptation measures even before the Climate Change Policy 2011 and NAPA came out (before 2011). After having the Climate Change Policy 2011 executed, the CFUG developed a CAPA identifying local impacts and necessary measures. The majority of the local adaptation measures were applied for landslides and water scarcity management (Table 7). The community built 45 check dams/gabion boxes benefiting more than 65 households and improved two walking trails in the village. The vulnerable community from the village retained better access to drinking water through the establishment of two water reservoir tanks in the two vulnerable villages within the CFUG; the protection of two water sources; water taps built for 72 vulnerable households; establishing 17 plastic ponds; a structure for rainwater harvesting at 200 households; and two sets of pumping water from the river for small irrigation. More than 130 improved cooking stoves helped to promote the economic use of fuel wood reducing pressure on the forest, which in turn helped preserve the water source in forests and improved people's health compared with using smokey ovens. 
Table 7. Adaptation activities by Rajdevi Community Forestry User Group while implementing a community-level adaptation plan of action.

\begin{tabular}{cccccc}
\hline SN & Infrastructures (Unit) & Before 2011 & After 2011 till 2017 & Total & HHs Benefited \\
\hline 1 & Earthen road (km) & 2 & 0 & 2 & 180 \\
2 & Walking trails (km) & 2 & 1.5 & 3.5 & 200 \\
3 & Water reservoirs tank (no.) & 1 & 2 & 2 & 2 \\
4 & Water source protection (no.) & 0 & 72 & 72 & 202 \\
5 & Water tap (no.) & 0 & 17 & 220 & 2 \\
6 & Water pond (no.) & 20 & 200 & 19 & 220 \\
7 & Rainwater harvest (no. of household) & 0 & 130 & 20 \\
8 & Pumping water from river (no.) & 20 & 45 & 45 & 150 \\
9 & Improved cooking stoves (no.) & 0 & 3 & 5 & 65 \\
10 & Check dam/Gabion box (no.) & 2 & 0 & 1 & 242 \\
11 & Fire lines (meter) & 1 & & 180 \\
\hline
\end{tabular}

As an implication of the adaptation program, Rajdevi CFUG found some subtle changes within the community in the areas of enhancing adaptive capacity. The constructions of erosion control measures created a safe environment for them; the pumped water from river supporting fish farming and irrigation, improving health and sanitation through enhanced access to drinking water due to water protection intervention. The protection of water sources, establishment of water reservoir tanks, and installation of water taps in individual households have contributed to improving the social and health condition of the community. In the past, people used to spend 3 to $6 \mathrm{~h}$ a day fetching drinking water from a very limited number of water sources. As a result of the water source management in the village, particularly with the installation of a water tap in each household, they do not have to spend a long time collecting drinking water. People, particularly women, saved time, which they now use to prepare food for getting their children ready for school in time. Children often used to go to school late. Similarly, people now have used this saved time for income-generation activities such as the brewing of local alcohol, an important source of rural income, and vegetable farming in the home garden.

The CFUG responded to climate change impacts by implementing several adaptation activities. Locally adapted measures showed that people are more concerned about water scarcity and the occurrence of landslides (Figure 2). People hardly responded to a loss of agricultural crops. Rather than taking any measures, nearly half of the households (30 out of 61 interviewed) left land fallow for about 10 years primarily due to insufficient rainfall and frequent drought. Five households managed to irrigate agricultural crops to deal with water scarcity. About one-fourth of total households still depended on rain-fed farming. To control landslides and erosion in the study area, the majority of the households (26) planted trees and were benefited from the constructions of check dams. Among the interviewed, $47 \mathrm{HHs}$ benefitted from water reservoir tanks built to store water. Community people also have protected water sources by fencing it with barbed wire and by constructing cemented structures.

The CFUG has allocated some forest lands to a group of poor people as a leasehold forest allowing them to cultivate grass and fodder species that helped poor people raise livestock. The lease provision benefitted 52 poor households.

An analysis of data with SPSS from a household survey shows that the food-insufficiency months have increased significantly from 2011 to 2016 ( $\mathrm{df}=60, p=0.005, \alpha=0.05$ ). The average food scarcity months from their agriculture was 7.26 months in 2011, which increased to an average of 8.48 months in 2016 due to sharp declines in the production of rice (Oryza sativa), maize (Zea mays), mustard (Brassica juncea), millet (Echinochloa frumentacea), lentils (Lens culinaris subsp. Culinaris), and black gram (Vigna mungo) because of the increasing draught and outburst of pest and insects such as caterpillars, slugs, and snails. As a coping strategy, some households have started to cultivate Ghaiya rice (Upland rice, 
which is a drought-resistant variety compared to Oryza sativa), but producing this crop is labor intensive.

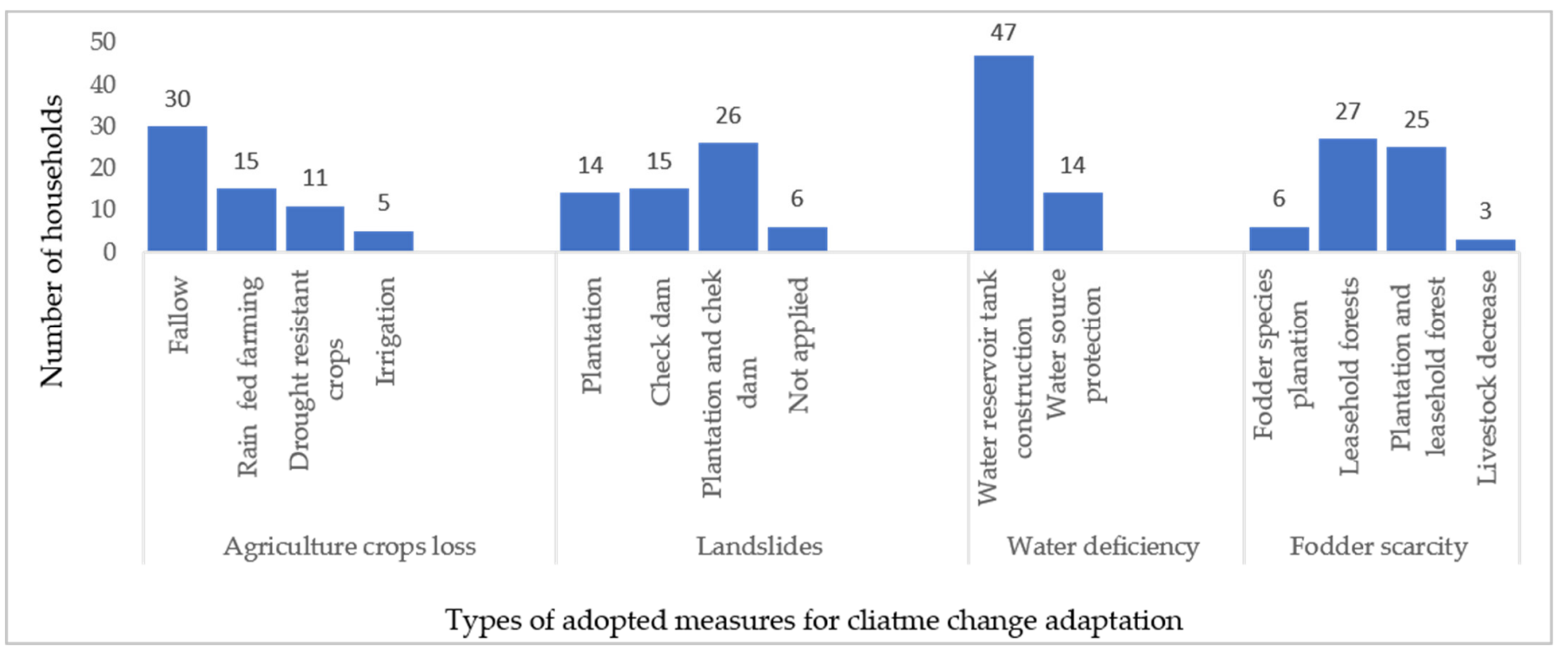

Figure 2. Climate change adaptation measures planned and implemented by households (according to CAPA implemented by Rajdevi CFUG for 2011-2016).

Community people experienced extreme impacts from the climate-induced hazards such as loss of agriculture crops and natural resources (e.g., land, forest tree species, reduced availability of water), damage to the physical properties (i.e., houses, livestock) as well as impacts on the human health (e.g., increasing mosquitos and related disease). People have not felt so much difference in terms of the severity of impacts between 2011 and 2016. However, the local community felt the need for the improvement in their coping strategies with technological advancement for drought and agriculture to deal with the climate-induced hazards and risks of agriculture.

\subsubsection{Shifting Local Priority toward Climate Issues}

Similar to other CFUGs in Nepal, Rajdevi CFUG conducts its activities based on its periodic forest management plan. Comparing the annual expenditure of the CFUG between 2011 and 2016 (Figure 3), nearly two-thirds of the budget has been spent on climate change adaptation activities in 2016, but it was hardly spent on such activities in 2011. However, the increased expenditure in 2016 is also due to the availability of additional funding coming from development partners for implementing such activities.

Comparing the annual budget for two years from the CFUG records shows that a total budget has increased nearly seven-fold from USD 1040 in 2011 to USD 7220 in 2016. The increased funding was from the project support for climate change adaptation. CARE Nepal (Hariyo Ban project/USAID) has supported this CFUG to develop and implement the CAPA. Given the substantial amount of funding coming from the external sources, it raises a question of the financial sustainability of the adaptation program in the community. However, the pattern of expenditure has been upward in climate change adaptation. Before the implementation of the climate change project, community development was the first priority of the CFUG, on which they spent $56 \%$ of their fund followed by the pro-poor program and forest management. In 2016, the distribution of expenditure differed considerably compared with the expenditure made in 2011. The climate change adaptation activities were the first priority with the expenditure of $63 \%$ on which no fund was allocated in 2011. The second important area of the expenditure was the pro-poor program with $27 \%$ of total expenses. It shows that the local community has prioritized climate change 
adaptation as a serious and urgent action. However, the consequences of the shift of focus from the pro-poor program to climate change adaptation activities remains to be assessed.

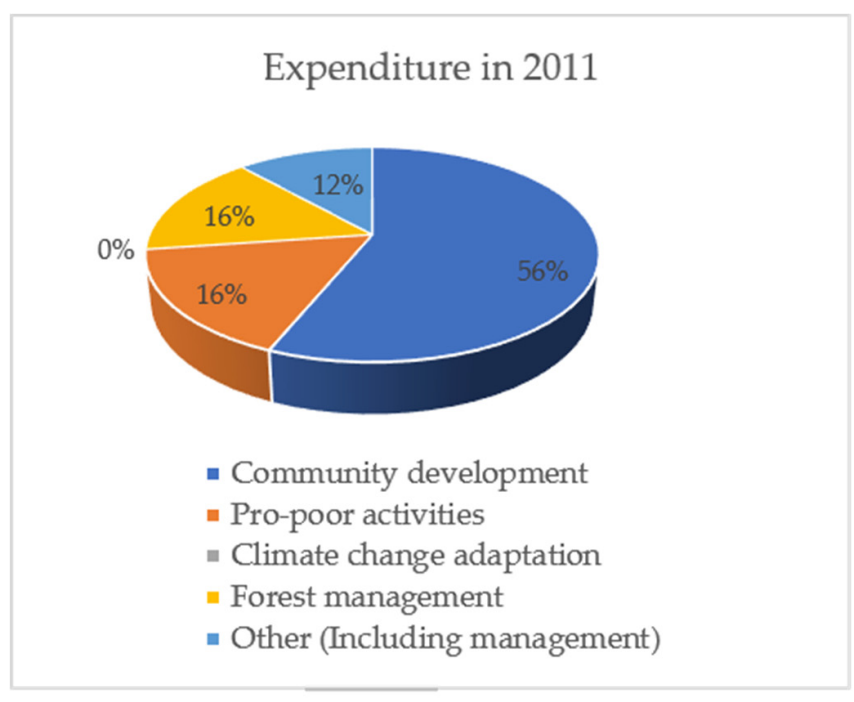

(a)

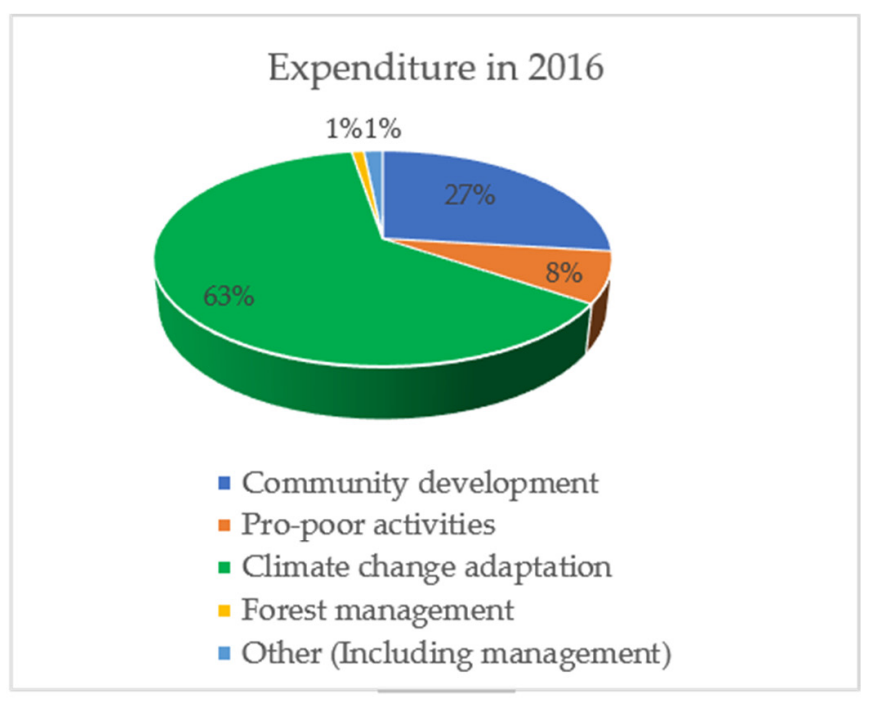

(b)

Figure 3. Comparing the CFUG expenditure in different activities between 2011 and 2016; (a) CFUG expenditure in 2011; (b) CFUG expenditure in 2016.

Analyzing the CAPA made by the community for 2012-2016, the total budget planned for this entire adaptation plan period was USD 24,068, of which nearly one-quarter of the budget (USD 5706) was borne by the community itself, and the rest was supported from the climate change project. The majority of the budget has been earmarked for the activities for water scarcity management (Figure 4). However, the budget for the upfront preparation of potential risk and hazards was nominal.

\section{CAPA activities budget (USD) share (2012-2016)}

\section{Outcome 4: Forest management and ecosystem}

Outcome 3: Income generation activities

Outcome 2: Pre-preparation for potential hazards

Outcome 1: Infrastructure for water scarcity management

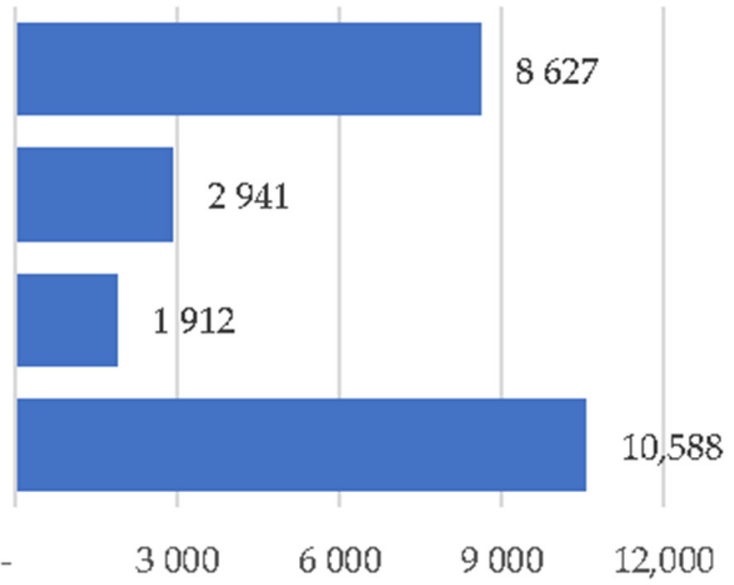

Budget

Figure 4. Budget share for different outcomes. 


\subsubsection{Overall CAPA Activities Linking to Policy Priority}

Through the development of CAPA, the CFUG has implemented adaptation activities that corresponded to the six thematic areas of NAPA. Local measures are adopted at the community (group) level and household level as per the needs identified by the community itself while preparing the CAPA. A wide range of climate change adaptation activities implemented by the community have reflected the aspirations of the policies (see Table 8). For example, the introduction of drought-resistant crops and kitchen gardens has supported agricultural production and food security. Forest nurseries, forest plantation, fire line construction, and the use of improved cooking stoves for the economic use of fuelwood have been contributing to forest and biodiversity conservation. Building water reservoir tanks for drinking water, water ponds to catch rainwater, pumping water from river, and harvesting of rainwater for irrigation provided the evidence of a strong desire of the community coping with water scarcity. Protection measures from landslides or erosion by constructing check dams, walking trail improvement, and roadside plantations are examples of climate-induced disaster management employed by the local community. Introducing improved cooking stoves, practicing kitchen gardens particularly for fresh vegetables, and installing individual water taps in the house connecting to water reservoir tanks have indicated that local people are becoming aware of health issues generated from climate change. Village road and walking trail widening provide an example of urban settlements and infrastructure development that the local community has initiated. In addition, leasing patches of forest to the economically poor HHs, the practice of providing interest-free loans to those poor households, and curtailing of timber quantity against as usual demand for regulating emergency use during climatic hazards were some strong examples of justice and equity which is a wider issue in both climate change adaptation and mitigation; in addition, it has been prioritized as an inter-thematic area in the new Climate Change Policy 2019 of Nepal. Comprising such practices developed and implemented by the local community, CAPA reflects the policy provisions into actions at the very bottom level: both community/groups and household levels.

Table 8. Major climate change response of Rajdevi CFUG in relation to NAPA.

\begin{tabular}{|c|c|c|}
\hline $\begin{array}{c}\text { Climate Change Policy and NAPA's } \\
\text { Thematic Priority }\end{array}$ & Locally Implemented Measures (CAPA) & Implementation Level \\
\hline 1. Agriculture and Food security & $\begin{array}{l}\text { Drought resistant crop e.g., Ghaiya } \\
\text { Kitchen garden }\end{array}$ & $\begin{array}{l}\text { Household }(\mathrm{HH}) \\
\text { HH }\end{array}$ \\
\hline 2. Forests and Biodiversity & $\begin{array}{l}\text { Plantation } \\
\text { Fire line in the forest } \\
\text { Improve cooking stove } \\
\text { Nursey promotion }\end{array}$ & $\begin{array}{l}\text { Community/Group } \\
\text { Community/Group } \\
\text { HH } \\
\text { HH }\end{array}$ \\
\hline 3. Water resources and Energy & $\begin{array}{c}\text { Water reservoir tank } \\
\text { Water pond } \\
\text { Pumping water from river } \\
\text { Rain water harvest }\end{array}$ & $\begin{array}{c}\text { Community/Group } \\
\text { Community/Group } \\
\text { Community/Group, HH } \\
\text { HH }\end{array}$ \\
\hline 4. Climate-induced disasters & $\begin{array}{c}\text { Check dam for landslide/erosion control } \\
\text { Trail improvement } \\
\text { Forest plantation }\end{array}$ & $\begin{array}{l}\text { Community/Group, } \mathrm{HH} \\
\text { Community/Group, } \mathrm{HH} \\
\text { Community/Group }\end{array}$ \\
\hline 5. Public health & $\begin{array}{l}\text { Water taps at households } \\
\text { Improve cooking stove } \\
\text { Kitchen garden-for vegetable }\end{array}$ & $\begin{array}{l}\mathrm{HH} \\
\mathrm{HH}\end{array}$ \\
\hline 6. Urban settlements and Infrastructure & $\begin{array}{l}\text { Earthen road improvement } \\
\text { Walking trail improvement }\end{array}$ & $\begin{array}{l}\text { Community/Group } \\
\text { Community/Group/HH }\end{array}$ \\
\hline Justice and Equity & $\begin{array}{c}\text { Allocate patch of forest } \\
\text { Supply of timber quantity reduced from } 30 \\
\text { cubic feet/HH per annum to } 22 \text { cubic feet/HH } \\
\text { per annum } \\
\text { interest free loan }\end{array}$ & $\begin{array}{c}\mathrm{HH} \text { (poorest of the poor } \mathrm{HH} \text { ) } \\
\text { Promote forest/support vulnerable } \\
\text { Poor }\end{array}$ \\
\hline
\end{tabular}




\subsubsection{CFUG's Practices as Complementary to Climate Change Policy 2019}

In addition to CAPA implementation, Rajdevi CFUG has implemented a number of activities as a regular program following the Community Forest Operational Plan (CFOP) which are directly and indirectly contributing to the goal and objectives of climate change policies and strategies as complementary measures (Table 9).

Table 9. CFUG's practices and activities complimentary to the overall climate change policies adopted in Nepal.

\begin{tabular}{|c|c|}
\hline $\begin{array}{l}\text { CFUG's Activities Implemented while Executing the Forest } \\
\text { Management Operational Plan }\end{array}$ & $\begin{array}{l}\text { Complementing Areas of Climate Change Policies } \\
\text { (Complementary to the Policy) }\end{array}$ \\
\hline Well-being ranking & $\begin{array}{l}\text { Vulnerability assessment (Climate Change Policy 2019, NAPA, } \\
\text { PAPA, LAPA) }\end{array}$ \\
\hline Pro-poor forest product distribution & $\begin{array}{c}\text { Priority to poor and climate vulnerable people, } \\
\text { distributional equity }\end{array}$ \\
\hline $\begin{array}{l}\text { Allocation of forest land to small groups of the poorest of the } \\
\text { poor CFUG members }\end{array}$ & $\begin{array}{c}\text { Contribute to reducing vulnerability of poor people, } \\
\text { distributional equity }\end{array}$ \\
\hline Interest-free loan for income generation activities & $\begin{array}{l}\text { Access to finance or loan particularly for vulnerable and } \\
\text { poor people }\end{array}$ \\
\hline Establishment of local saving and credit cooperatives & Emergency use for all \\
\hline
\end{tabular}

In Nepal, it is mandatory for every CFUG to prepare a CFOP and a CFUG constitution. The CFUG is an autonomous entity; however, the CFOP and the CFUG constitution should be approved by the DFO, which is a competent authority for monitoring the CFUG activities. In accordance with the Forest Regulation 1995, Forest Act 2019, or CFUG Formation Guideline 2014, the Rajdevi CFUG has prepared the CFOP and CFUG constitution. The CFUG formation guidelines have specified the guidelines to prepare the CFOP and CFUG constitution. Ensuring the active and meaningful participation of each CFUG member (household) is a must while preparing the $\mathrm{CFOP}$ and constitution. After the climate change adaptation project has been implemented, the Rajdevi CFUG has amended some rules and regulation according to the needs of CFUG members to address local issues related to impacts of climate change. First, the CFUG changed the rule about timber distribution to control its unfair consumption. Before the introduction of the climate change adaptation project, each of the CFUG members was entitled to receive timber up to 30 cubic feet (cft) per household per year without any charge. The quantity is reduced to $22 \mathrm{cft}$ after the implementation of the project. The analysis of the data from the household survey showed that the quantity of timber used from the community forest reduced drastically from $24.1 \mathrm{cft}$ per $\mathrm{HH}$ in 2011 to $1.98 \mathrm{cft}$ per $\mathrm{HH}(\mathrm{df}=60, p=0, \alpha=0.05)$ in 2016. Similarly, the amount of fuel wood use has decreased from 102.36 Bhari (1 Bhari $=$ approximately $35 \mathrm{~kg}$ ) in 2011 to 69.75 Bhari ( $\mathrm{df}=60, p=0.001 \alpha=0.05)$ in 2016 due to the introduction of improved cooking stoves for the economic use of fuel wood in the household.

The results from the FGDs and expert interviews also complemented that the use of LP gas has also contributed to reducing the fuelwood consumptions. It infers that decreasing amounts of using forest products by the CFUG can contribute to increasing the growing stock in the forest, which would be available to climate-affected individuals when they need (as suggested in group discussions). The increased biomass stock in forests may enhance the climate change mitigation benefits from the forest. In addition, the CFUG changed a rule for the entry of a new member to the CFUG (for example, immigrants to the village). In the past, the newcomers were restricted to use timber from the forest for 5 years. They were only allowed to use fuelwood and fodder. However, considering the risk and vulnerability from climate change, the CFUG uplifts the restrictions of the five years for the new CFUG members. Such changes in the rules show that community people are more pragmatic to promote justice in tackling climate change impacts in a due consideration of allowable amounts prescribed in the CFOP. Furthermore, the CFUG modified the timber-harvesting rule. In the past, the users who demanded timber, after approval by the committee, were allowed to enter the community forest and cut those trees 
to the size and the quality they desired. However, now, committee members themselves are involved in selecting and cutting the trees with the technical assistance of a competent forest officer who is responsible for monitoring CFOP activities. This rule helps to reduce damages in the forest during harvesting, thereby contributing to reducing the harvesting damage to the residual forest stands.

On top of that, the CFUG promoted leasehold forestry within community forests to support economically-deprived households. The poorest of the poor members, based on the well-being ranking, are eligible for the leasehold forestry groups. The CFUG supported two leasehold forestry groups. Each group comprises of 28 households. They are provided with forest land in which they could manage forests as they need. The CFUG constitution and CFOP allow them to cultivate cash crops in the leased forestland; for example, they have planted broom grass (Thysanolaena maxima). They can establish forest plantations of the species of their need and preferences, e.g., preferred fodder species. In practice, they have further divided the leased forestland among themselves, and each household possesses about 0.25 hectares of it. Each group has been provided with NR 50,000 (USD 500 approximately) as a revolving fund for income generation activities: for example, bee keeping, pig rearing, goat keeping, and broom grass cultivation. From this fund, poor people use up to NRs 10,000 (USD 100 approximately) for two years as an interest-free loan for income-generating activities. A member received seedlings from the nursery established by the CFUG.

\subsection{National Policies and Local Implementation: Gaps between Climate Change Policy 2019, $N A P A$, and LAPA}

Although a handful of examples of coherence between the policies were identified, there were also some contradictions between them. Based on the review of the policy documents, expert consultations, and field observation, major gaps and contradictions are presented in Table 10.

As depicted in Table 10, there are policy breaches for the implementation of climate change adaptation programs at the local level. Some of the major gaps includes unclear implementing units, a lack of proper fund channeling, capacity development of local government authority, and program for food security and technology development for agriculture promotion at the local level.

NAPA assumes that the individual line ministries will take responsibility to mainstream climate change adaptation into their sectoral plans instead of developing a separate adaptation plan. However, the LAPA framework has been developed for preparing a locallevel climate change adaptation plan and implementation. It seems there is a conceptual gap between these two frameworks. A lack of outright direction about how local-level adaptation plans could be mainstreamed in the regular development process might be a consequence of this confusion.

At a local group or community scale, CAPAs have been formulated following the steps of the LAPA framework and implemented by community-based groups including CFUGs [61] as proposed in the NAPA. As explained in the results, CAPA and the associated CFUG have demonstrated that they are capable of translating policy provisions into local actions. The Guidelines for the Community Forestry Development Program 2014 has also provisioned CAPA and been approved on the 22nd of July 2014 [70] (p. 15). According to this guideline, a CFUG can develop a local-level climate change adaptation plan based on the local context. However, these plans are rarely recognized and approved by the DFO for a couple of reasons, as suggested by expert interviews including government officials. First, the knowledge gap: most of the government staff members working locally have limited knowledge about climate change issues, how it happens, and what can be done to tackle them. Although the Climate Change Policy 2019, NAPA, and LAPA have been formulated to address climate change impacts, the local government officials seem unaware about the content of the policies and plan. In addition, the government does not have sufficient funding and a sound mechanism for building staff capacities. Second, the participation of government staff in the CAPA preparation process was not encouraged. In 
most cases in the CAPA preparation process in Rajdevi CFUG, responsible government officials did not participate (based on group discussion). Project and community sought the participation of the government staff only to get their signature (any of DFO's staff) in any one of the meetings. And thirdly, insufficient resources: in terms of human resource, DFO has a very limited number of local staff to work. According to a local government staffer from DFO, they have to handle many other important tasks covering large geographical working areas, besides climate change. Financially, the Government of Nepal is not in a position to allocate sufficient financial resource for staff as Daily Subsistence Allowance (DSA), and the adaptation project also does not offer sufficient DSA to get them involved in the entire process of CAPA preparation. Some experts argue that CAPA does not need an approval from the DFO. This is an overall adaptation plan of a particular community developed through the process of household level planning (e.g., household level livelihoods improvement plan) that seeks to cope with urgent climate risk and vulnerability and build resilience against spontaneous and anticipated climate change impacts. According to the experts, the community needs a DFO approval only for those activities which are planned to be carried out inside the forests and are likely to damage the forest. It suggests that CAPA and their effectiveness, and involvement in local adaptations are not addressed in national policies and strategies, thereby overlooking the overall development process.

Table 10. Gaps between climate change polices and local level implementation of climate change adaptation program.

\begin{tabular}{|c|c|c|}
\hline Policy Provision & Gaps and Contradictions in Implementation & Consequences \\
\hline $\begin{array}{l}\text { NAPA does not spell out any separate plan for adaptation; rather, } \\
\text { it presumes that sectoral ministries would mainstream the climate } \\
\text { change adaptation into their sectoral plans. }\end{array}$ & $\begin{array}{l}\text { Although LAPA emphasized integrating } \\
\text { climate change adaptation into local } \\
\text { development planning, it has focused on the } \\
\text { development of separate climate change } \\
\text { adaptation plans. }\end{array}$ & $\begin{array}{l}\text { Created confusion of providing a proper } \\
\text { institutional framework for integrating an } \\
\text { adaptation program of line ministries into } \\
\text { locally developed climate change } \\
\text { adaptation plans. }\end{array}$ \\
\hline $\begin{array}{l}\text { The Climate Change Policy } 2019 \text { does not explicitly determine the } \\
\text { implementing unit; however, it emphasized that the local } \\
\text { adaptation plan was intended to households and the community. } \\
\text { "Adaptation measures will be adopted in line with local and indigenous } \\
\text { knowledge, skills and technologies by identifying climate change affected } \\
\text { households, communities and risk zones (Climate Change Policy 2019)". } \\
\text { However, NAPA is clear about implementing units that local level } \\
\text { groups can implement as adaptation programs. "Program/project } \\
\text { implementation through existing community level organization/s like } \\
\text { CFUG, different farmers groups, irrigation groups and other interest } \\
\text { group (NAPA 2010)". }\end{array}$ & $\begin{array}{l}\text { LAPA emphasizes that local governments } \\
\text { ought to prepare and implement adaptation } \\
\text { programs. "Local government will prepare } \\
\text { climate friendly adaptation plan and implement } \\
\text { (LAPA 2019)". LAPA suggests to select and } \\
\text { prioritize adaption measures at the ward, } \\
\text { municipality, and rural municipality level. }\end{array}$ & $\begin{array}{l}\text { Role of community-level institutions has } \\
\text { been overlooked/negated, because LAPA } \\
\text { does not recognize CAPAs. }\end{array}$ \\
\hline $\begin{array}{l}80 \% \text { of climate budget should reach the local community. } \\
\text { "Mobilization of at least } 80 \text { percent of amount will be ensured for } \\
\text { implementation of programs at the local level (Climate Change } \\
\text { Policy 2019)". }\end{array}$ & $\begin{array}{l}\text { No clear mechanism for expenditure } \\
\text { and authority. }\end{array}$ & $\begin{array}{l}\text { Vulnerable people lack access to } \\
\text { available funding. } \\
\text { More expense in district level meeting, } \\
\text { workshop, etc. }\end{array}$ \\
\hline $\begin{array}{l}\text { Food security and technology development for } \\
\text { agriculture promotion. } \\
\text { "Food security, nutrition and livelihoods will be improved by adopting [a] } \\
\text { climate-friendly agriculture system (Climate Change Policy 2019)". }\end{array}$ & $\begin{array}{l}\text { Lack of concrete program at the local level for } \\
\text { food production and security (in } \\
\text { LAPA framework). }\end{array}$ & $\begin{array}{l}\text { Duration of food insufficiency has been } \\
\text { increased at a local level. } \\
\text { Kept lands fallow due to the high insurgency } \\
\text { of drought period (lack of introducing } \\
\text { drought-tolerant crops). }\end{array}$ \\
\hline $\begin{array}{l}\text { FUG's CAPA translated most of the policy prioritized actions } \\
\text { mentioned in Climate Change Policy } 2019 \text { and NAPA. }\end{array}$ & $\begin{array}{l}\text { However, CAPA are not legitimized as an } \\
\text { implementing unit in the LAPA framework. } \\
\text { DFO does not take the responsibility to } \\
\text { approve it. } \\
\text { Progress of the CAPA is not reflected in any } \\
\text { of the government official reports. }\end{array}$ & $\begin{array}{l}\text { Lack of funding for CAPA implementation } \\
\text { Majority of the CAPA became functionless } \\
\text { due to lack of funding after accomplishing } \\
\text { the first duration (dormant). } \\
\text { Struggling for legitimacy. }\end{array}$ \\
\hline $\begin{array}{c}\text { Capacity development of local government authorities } \\
\text { including DFOs. } \\
\text { "Capacity of relevant governmental, non-governmental and academic } \\
\text { institutions and community associations/organizations of all three levels } \\
\text { will be enhanced to mainstream climate resilience into development } \\
\text { programs (Climate Change Policy 2019)". }\end{array}$ & $\begin{array}{l}\text { No clear mechanism and program for } \\
\text { capacity development of local } \\
\text { government authorities. }\end{array}$ & $\begin{array}{l}\text { Communities rely on temporary } \\
\text { project's staff. } \\
\text { Lack of coordination with } \\
\text { government authority. } \\
\text { Paucity of local government authority's } \\
\text { participation in the CAPA process. }\end{array}$ \\
\hline
\end{tabular}

\section{Discussions}

5.1. How Are Climate Change Policies Coherent? Contents and Provisions of Climate Change Policy 2019, NAPA, and LAPA

The Climate Change Policy 2019 [10], NAPA [61], PAPA [66], and LAPA framework [67] are the major policy instruments dealing with climate change adaptation issues in Nepal. As highlighted in the results (Table 4), enhancing the socio-economic prosperity 
of the nation by building climate resilient society, the adoptive capacity of individuals, groups, and communities through developing a suitable institution and organizational framework at all levels-national, provincial, and local levels are the common aspirations enshrined in these policies. The NAPA recognizes the importance of linking local adaptation with national-level policies and plans through the implementation of LAPA and the management of available local assets, including natural resources. The NAPA document is very specific in mainstreaming Community-Based Adaptation (CBA) because it emphasizes the need for integrating the local adaptation priorities of the most vulnerable communities [71,72]. NAPA as a national framework for climate change adaptation has made a provision of mobilizing existing community-level organizations such as CFUG, the Farmers' Group, Irrigation Groups, and other groups for adaptation planning and implementation. The Climate Change Policy 2019 provisioned the National Adaptation Plan (NAP), which is in the process of development. However, PAPA and LAPA are less explicit on mobilizing local groups in planning and implementation. The Climate Change Policy 2011, developed in line with NAPA, prioritized local community/groups for implementing climate change adaptation plans at a local level. However, the Climate Change Policy 2019 has given an emphasis on considering indigenous knowledge, skills, and technologies of households and communities in adaptation planning, but it is silent on the mobilization of those groups in adaptation program implementation. It has led us to argue that there is not only policy breach to ensure active participation of local people in climate change adaptation, but also the question of "will or attitude "of decision makers for policy reform toward mobilizing local groups. The Climate Change Policy 2019 is not explicit in entrusting implementation responsibilities to local groups. McLaughlin [73] argued that the success of polices fundamentally depends on the attitude and motivation of decision makers and implementers. The Environment Protection Act 2019 [74] has also addressed the provision of local community or groups for planning and implementation; nevertheless, it is poorly linked to the existing institutional framework.

LAPA, as a major framework for planning and implementation, has focused on the local government for the planning and implementation of climate change adaptation. The District Coordination Committee (DCC) and municipality /rural municipality have been entrusted with a lead role for planning and implementation at the local level. This has aligned with the Local Government Operation Act 2017 that provided the local development framework with specific roles of local governmental institutions including municipalities/rural municipalities [75]. Designating the DCC and municipality/rural municipality as a key agency for adaptation planning and implementation at local level, to some extent, has resolved the issues between the Local Government Operation Act 2017 and Forest Act 2019. The Forest Act 2019 entrusted DFO with the overall authority of forest management in the district [76]. As explained by Tiwari et al. [77], the LAPA development process offers opportunities for local communities and households to assess location-specific climate vulnerabilities, identify adaptation alternatives, and implement urgent and immediate climate adaptation actions. It intends to implement the priority programs and project of NAPA more effectively through public and local participation and integrating adaptation into the sectoral plans and policies. LAPA links local adaptation practices with national policies as it connects community-level adaptation planning into the overall development planning process at the ward and municipality level [78]. Given the scenario, it suggests that the policies are all coherent to acknowledge the objective of reaching out to the vulnerable communities, groups, and individuals but are seemingly fragmented for mobilizing those communities for implementation. They also commonly show an integrative nuance of integration of adaptation plans into the planning process. This sets an example that policies are coherent. However, they exhibited an incoherent nature when it comes to institutional units for implementation, inferring local government by LAPA and local community by NAPA. England et al. [79] found similar results in climate change adaptation policy analysis across southern Africa, indicating the need for improvement in vertical coherence between national policy and district-level climate change management plans as well as sectoral 
coherence. The different environmental policy coherence analysis of the European Union (EU) showed that the policies were coherent at the level of objectives but contradictory at the level of implementation [15]. The recent study between climate change policies and forest policies of Nepal showed similar findings that policies are more consistent on the level of motivation and adaptation measures, but on the level of implementation, they are less coherent [25]. Fernández-Blanco et al. [80] also highlighted the contradicting aspects among institutional elements of sustainable forest management regime. They found strong conflicts between the goals of explicitly strengthening the roles of indigenous peoples as civic actors and those explicitly supporting national governmental actors.

\subsection{How Climate Change Policy Provisions Are Translated into Local Actions? A Case of CAPA Implementation by CFUG}

A successful climate change policy needs to involve most affected local groups [81] as the impacts of climate change are intrinsically local context-specific, thus needing interventions at the local level $[82,83]$. Reflecting the implementation of the climate change adaptation plan at the local level, the Rajdevi CFUG from the central mid-hills of Nepal has shown noticeable results of planning and implementation, translating the national policy priority into local actions. To develop CAPA, the CFUG undertook a participatory vulnerability and impacts assessment; identification of response options; and implementation of selected measures considering essential social and equity issues in the community, setting an example of the implementation of climate change policy at the local level. As depicted in the results (Table 8), the implemented activities of CAPA mostly represented the thematic areas of NAPA. Previous studies reported many CFUGs already supporting health service, irrigation, drinking water, education and rural transportation service for their community members [84], which seem complementary to the goal of Climate Change Policy. The regularly implemented activities of CFOP of Rajdevi CFUG (Table 8) showed that the CFUG has already implemented some measures related to climate change adaptations complementary to Climate Change Policy provisions. Noticeable practices of the CFUG include the fact that 35\% of CFUG's income [70] has to be allocated for poor and marginalized communities, which partially resembles the $80 \%$ of climate fund mentioned in the Climate Change Policy to reach the local community. Such provisions are aligned with the essence of distributional equity. The CFUGs implement it on the basis of categorization of users through the well-being ranking, which is remarkably complementary to the aspiration of vulnerability assessment of national Climate Change Policies as well as the IPCC guideline of climate change vulnerability assessment.

The CFUG has implemented a number of adaptation measures. The community assessed water scarcity and climate-induced disasters (landslide and erosion) as major climate change issues experienced at the local level, thereby focusing more on water-related issues followed by responses to climatic disaster. This finding of vulnerability assessment corroborated the findings of a national climate change impact survey report of Nepal 2016. The report showed that drought as a climate-induced disaster, erratic rainfall, and an increased incidence of landslides over the last 25 years affected many rural households and economies [85]. In terms of the sensitivity and severity of climate change, landslide and erosion were dire because they tended to massively destroy people's lives and livelihood assets. The Nepal Disaster Report 2015 showed that 487 persons were killed, 473 were injured, 39812 families were affected, 5282 animals were killed, and there was an equivalent economic loss in disaster of $16,753.7$ million rupees, particularly from floods and landslides in 2014 [86].

The community has become very sensitive toward social justice and equity. While the previous studies $[34,87]$ found that the LAPA failed to address the social equity and justice issues of sustainability, the CAPA has made some contribution to enhancing social equity and justice through community actions. Formulating rules to address an unfair distribution of forest resources, interest-free loans to climate vulnerable people, and the leasing productive patches of forest areas to the poor and vulnerable groups are key examples of community-led activities associated with social justice and equity. These 
practices are highly compatible with the spirit of the Climate Change Policy. Such practices may be regarded as an integral part of the sustainable adaptation strategies suggested by Eriksen and Brown [88].

The local measures discussed here are directly and indirectly linked to the six thematic areas identified in the NAPA. It implies that CAPA implementation by the community or local groups is relatively effective for the preparation and implementation of a local climate change adaptation plan. This finding resonated with Paudel, Ojha, Karki, and Gurung [35], who argue that local organizations such as CFUGs and agriculture groups have been proved effective in implementing adaptation activities. Matias [89] has also revealed similar results that a group of indigenous Palaw'ans in the Philippines exhibit a significant capacity for collective action in the maintenance of the water system as part of an adaptive response to climate change. The Palaw'an community has formed a local water users' association called Danum na Buwal et Mundugen, which agreed on the terms and actions on the maintenance of the water system. They planted fruit-bearing trees monthly along the water pipes and also cleaned the water tanks. As suggested by Laidler [90], local people have robust instinctual understanding of local atmosphere from their close interaction with nature all along ever since they started to sense environmental changes. They struggle against climate-induced problems; thus, their participation in climate change policies and program implementation are indispensable. Therefore, there is mounting realization of the need and the importance of local groups and institutions in the planning and implementation of adaptation activities at a local level [82,91-93]; nevertheless, local institutions have barely received any attention for adaptation issues, policy, and strategies [91].

\subsection{Gaps Hindering the Policy Coherence and the Localization of National Policies}

\subsubsection{Ambiguous Institutional Framework for Implementation and Coordination}

Nepal's Climate Change Policy 2019 covers diverse issues linked to climate change and highlights the need for engaging a wide range of stakeholders at the national and local levels. The policy is silent in terms of entrusting responsibility to the local level institutions and organizations to implement adaptation interventions. However, the NAPA focuses on planning climate change adaptation through existing local community-based organizations. The LAPA framework concentrates on the ward/municipality/rural municipality (local government's structure) for planning and implementation. The LAPA framework talks about an identification of local knowledge and experiences practiced by households, groups, and communities; it even allows them to prepare community-based adaptation plans. However, it has failed to integrate them into the local government's planning process, remaining silent on such plans and community-level organizations. Therefore, there is a huge policy ambiguity about the role of community organizations for planning and implementing adaptation activities at the local level. Although the LAPA emerged as a pioneering planning means to allow the adaptation process at the local level and trade-off between the top-down and the bottom-up approaches [94], the technocratic, top-down, and aid-driven adaptation policy is inadequate to address the vulnerability of people on the ground. Such an approach and policy overlook locally needed specific and contested realities of social dynamics and biophysical change [33]. As explained by Neupane et al. [95], climate change-related (or any environmental/biodiversity) frameworks should build upon already existing and well-functioning institutions. Therefore, a major gap between policy and implementation is likely to persist until the spontaneous as well as proactive activities of small community groups or households are articulated in the policies and strategies with clear and explicit local institutional setting and practical guidelines for implementation.

A coordination mechanism exists between line ministries; however, there is a lack of coordination between relevant institutions, particularly at the province level. Although the Forest Directorate (FD) has been given a responsibility to connect the MoITFE with district-level organizations, there is no direct coordination mechanism between FD, other directorates in the province, and DCC in the districts; therein lies a big gap in implementing 
adaptation programs in the districts. Therefore, such a working in silo approach would not only complicate the process of implementation but also have the probability of squandering resources by repetition of the same activities unnecessarily for the same target populations. Even at the district level, this issue has existed.

At the district level, the coordination mechanism is poor between relevant state and non-state organizations such as the District Agriculture Development Office, the District Livestock Service Office, the District Drinking Water Supply Office, and the District Soil and Watershed Management Offices when it comes to developing programs for local communities. None of the climate change policies offer a straightforward and coherent institutional operational framework for the implementation of climate change activities at the local level. The Climate Change Policy 2019, NAPA 2010, PAPA 2019, and LAPA 2019 deviate from each other for the local-level implementing unit.

The PAPA and LAPA are very clear about an implementing unit at the local level. They emphasize the local government's institutions (ward, municipality, rural municipality). NAPA is outright for local-level community institutions as a planning and implementing unit. It states as "Program/project implementation through existing community level organization/s like CFUG, different farmers' groups, irrigation groups and other interest group (NAPA 2010)". The Climate Change Policy 2019 is unclear about recommending an implementing unit compared to the previous Climate Change Policy 2011. The Climate Change Policy 2011 states: "Emphasizing the participation of government, semi-government, NGOs and user groups in formulation and implementation of programs related to climate adaptation, GHG mitigation, capacity building, technology development and extension (Climate Change Policy 2011)". The Climate Change Policy 2019, acknowledging the existing adaptation practices, states: "Local Adaptation Plan has been introduced at various vulnerable areas as per LAPA framework. Similarly, Community Based Adaptation Plan is being implemented at community level with the support of various community organizations, civil society, private sector and other institutions (Climate Change Policy 2019). Concerning the implementation, it states "Adaptation measures will be adopted in line with local and indigenous knowledge, skills and technologies by identifying climate change affected households, communities and risk zones (Climate Change Policy 2019)". This statement hardly talks about the identification of implementing. It suggests that this policy might have a nuanced understating of local governments as implementing units.

The Climate Change Policy 2019 shows a promising strength in terms of differentiated impacts and vulnerability of climate change: "Concerns of women, Dalit, indigenous people, Madheshi, Tharu, Muslim, oppressed groups, backward class, minorities, marginalized, farmers, laborer, youths, children, senior citizens, persons with all forms of disability, pregnant women, incapacitated and disadvantaged persons or groups will be addressed in matters related to climate change". As explained by various studies [2,3,96-98], climate change impacts are differentiated considering different dimensions, for instance, the level/context of vulnerability of individuals, groups, communities, gender, poor, marginalized, minorities, disability, elderly and children. The Climate Change Policy 2019 has rightly considered those differentiated impacts, which are common in developing countries ([99]. As stated in the results, NAPA looks committed to internalize adaptation programs into sectoral plans of the individual line ministries and to mobilize local communities and groups for implementation. However, concentrating programs in the political boundary of local government poses critical questions of reaching the diverse target populations mentioned in the policy. Climate Change Policy and NAPA provide the MoFE with the responsibility of the overall functional coordination, but local government officials at the implementing unit are more accountable to the Ministry of Federal Affairs and Local Development (MoFALD) [35]. There is an argument that the DCC/ local government tends to consider itself as the local agency of the MoFALD rather than being a local government, and this ministry (which is responsible for local government) does not perceive climate change as their mandate, too. This may have discouraged other ministries to rely on the local government in delivering their climate change-related programs [35]. 
The Climate Change Policy has promised that at least $80 \%$ of the climate change funds will reach the local communities. However, it does not provide a concrete mechanism of fund disbursement earmarked for the local communities. Interviews with project staff and policy makers suggested that the allotted $80 \%$ project fund has reached at least the district headquarters but not the local communities. Expert opinion who closely worked on adaptation program estimated that about $50 \%$ of the climate fund has reached the local communities to implement locally identified climate adaptation activities. An increasing number of discussions such as workshops, seminars, and meetings squandered a large share of the fund at the district level for two important reasons: first, due to the lack of clear procedure to get the budget delivered to the target beneficiaries, and second, climate change activities are not clearly defined for the allocation of fund. Nepal introduced a climate change budget code in the 2012 [100]; however, the criteria to apply for the climate change code remains unclear, and it influences the realistic estimate [101].

\subsubsection{Insufficient Information, Knowledge and Capacity Related to Climate Change} Impacts and Adaptation Measures for Policy Implementation

The NAPA was formulated based on the vulnerability assessment using an Intergovernmental Panel on Climate Change (IPCC) framework [60]. However, due to the absence of reliable location specific meteorological data, the NAPA used expert judgment in ranking the vulnerability of different districts [61]. The views of experts may not represent the real climate impacts experienced by local people. This is possibly the biggest limitation of NAPA; thus, it has been challenging for policy makers, climate experts, and practitioners to identify appropriate local adaptation measures. The role of climate science, analyzing climate change impacts and the intervention of technologies for location-specific adaptation measures have been key issues in the planning process [34]. Therefore, we urge for an in-depth study of local perceptions of climate change and their consistency with local meteorological records to have a full range of impacts assessment. Where there is dearth of climatic records or limited observational climate data, local people's understandings provide a foundation to determine changes in climate variables and trends [47].

Local people are very sensitive to climate change and its impacts, thereby exploring adaptation measures from their intuitive understanding gained through their constant interactions with daily weather change [90]. Community requires knowledge and practical ideas to deal with the critical periods of stresses within their farming system and livelihoods. The Climate Change Policy 2019 speaks about ensuring food security through agricultural interventions. However, it is hardly reflected in the local-level adaptation plan and actions. In addition to some practices of drought-tolerant crops and kitchen gardens for vegetables on private land, CAPA has also failed to implement any profound activities on food production and security. Increasing food insufficiency in the studied community in 2017 over 2011 confirms the severity of the issue. The community has been facing extreme impacts such as crop failure, declining crop productivity due to drought, pest and diseases, health, and the depletion of resource issues.

The poor performance of agriculture has been triggered by multiple factors including climate change, low incentives to intensification, poor market access, unfavorable topography, and poor soils [102]. Most poor and developing countries are located in the tropics and semi-desert areas exposed to rising temperature and a water shortage [103], and they face severe climatic threats to crop production due to their geographical location [60]. The FAO anticipates that the decline in agricultural production is likely to affect the availability of food in South Asia and sub-Saharan Africa, where the majority of the population are already vulnerable due to poverty and weak coping capacities to climatic stresses [104]. Most of the African governments have already initiated governance for various adaptation strategies including improvement of technologies and infrastructure, livelihoods' options, and agriculture diversification [60].

In Kenya, farmers are encouraged to practice crop management such as use of diversified crop cultivars, planting of early maturing crops during short rainy seasons, planting of drought-tolerant cultivars, and the use of low planting densities during the dry sea- 
son [105], soil and water conservation through land contouring and terracing, mulching, conservation tillage practices, and integrated soil fertility management [106]. Replacing water resource-intensive systems (e.g., rice-wheat system) with less water-intensive cropping systems (e.g., maize-wheat system) can increase the adaptation of water stress in agricultural production [107]. Crop diversification improves a buffering of crop production under climatic stress by reducing the chances of pathogen transmission that may arise due to increased climatic variability [107]. For example, Lin [108] found that the planting of disease-susceptible rice varieties in mixtures with resistant varieties had $89 \%$ more yield and $94 \%$ reduced the occurrence of fungal blast when planted in monoculture. Georgopoulou et al. [109] found that there is a clear distinction between northern and southern Greece in terms of losing and winning agricultural yields in a changing climate. They suggested that climate change adaptations on agriculture need to be tailored to both geography and crop diversity even in a comparatively small country. Given these examples, the community-based adaptation plan of Nepal principally requires an adjustment with cropping pattern change and agriculture diversifications pertaining to the regional and topographical variations.

The limited capacity of the local governments for climate change adaptation planning and implementation poses a major constraint for translating national policy into local plans/actions. The capacity of the government authority, staff, and stakeholders working on climate change issues is not adequate for effective implementation of the climate change adaptation activities at the local level. A discussion with experts (policy makers, climate change specialists) and group discussions suggested that there is a capacity and knowledge gap among different stakeholders that has led to the development of poor linkages between national plan and local needs about climate change, causing some of the urgent local needs to be unaddressed. Khatri, Bista and Gurung [59] also showed that the local government in Nepal lacks capacity to make the best use of available climate change information and knowledge. There are critical gaps on the capacity within the government planning sector in addressing climate change as cross-cutting issues [110,111]. Dongol and Heinen [112] argued that the shortage of adequate staff (both qualitative and quantitative) for the management and enforcement of policy across multiple layers of government and institutions can lead to a failure of policies by making implementation unfeasible. McLaughlin [73] highlighted two broad factors: local capacity and will. He added that although the capacity is undeniably a difficult issue, policy can address it by furnishing missing expertise but will or the attitudes, motivation, and beliefs that inhibit an implementer's response to a policy's goal is less manageable for policy intervention.

Eriksen, Nightingale and Eakin [32] theorize the politics of adaptation and propose the concepts of authority, knowledges, and subjectivities to analysis of adaptation, emphasizing a socio-political process that mediates how individuals and collectives deal with multiple and coexisting environmental and social changes. They highlighted how "power and politics" shape resource access, control, and distribution, which is insufficient even if adaptation policies and program explicitly focus on it.

Authority in climate change adaptation draws the attention to formalized institutions and organizations at different scales [113]. Knowledge increases an accuracy in making decisions related to adaptation [114], and subjectivity helps to link the exercise of power to uneven social connection and individual agency [32]. The interactions between these three elements are fundamental to the explanation of climate science [115], diversification of resources, targeted populations and regions, and knowledge about the critical issue of survival in climate change stress and to implement adaptation activities [32].

The struggle between these three components is believed to be influenced by how policy is formulated and implemented such as top-down and bottom-up. The top-down approach identifies a community of interest organizations on the basis of the thought of political activities in relation to ongoing policy processes [116], and bottom-up identifies the size and composition of entire interest groups and all potential organizational entities which are politically active but are not essentially engaged actively in seeking actual policy 
influence $[116,117]$. Analysis of the key climate change policies of Nepal suggests that the policy formulation process and implementation of Nepal is hybrid, showing the necessity of greater flexibility in the design of programs and initiatives for local adaptation. The study from Indonesia also found that the local influence of ideas and preferences to the upward central level policy was limited, suggesting the need to pay attention to local actors engaged in the planning processes to inform decision making at higher jurisdictional levels [118].

Overall, this study highlights profound climate change impacts faced by CFUG households at the local level. The impacts are directly and indirectly linked with agriculture-based livelihoods facing water shortage, increased drought intensity, and landslides escalation. The implementation of both CFUG's Community Forest Operational Plan and CAPA have shown noticeable contributions to address such issues reflecting national climate change policy's aspiration at the local level.

Out of the approximately 2500 CAPAs in Nepal, most CAPAs prepared and implemented by the CFUGs include adaptation activities related to drinking water, irrigation water, protection from landslide, afforestation, and forest protection. The prioritization of similar activities may be constrained by the available budget and time frame provided by the adaptation projects. CFUGs, particularly in the middle and high Mountain regions, tend to respond to the most pressing problems at first such as water scarcity, landslides, and climate-induced consequences to agricultural crops. In this context, the findings of this study are equally applicable to the wider geographical contexts of Nepal as well as similar community-based adaptation practices with analogous geographical and livelihood systems around the developing world.

\section{Conclusions}

In this paper, we have attempted to assess coherence between national climate change policies/plans, and local adaptation plans and actions. We have explored the localization of national policies in Nepal. The Climate Change Policy 2019, NAPA, PAPA, and LAPA exhibit both coherent and contradictory characters. Particularly, climate change policies are coherent for targeting vulnerable communities, households, or individuals but found to be deviated for recommending an appropriate implementing unit. The LAPA and PAPA consider the local government as implementing units while the NAPA puts an emphasis on the local community group for implementation. Our policy document analysis and fieldwork in a local community in rural Nepal suggested that national policies deviate from each other, creating confusion among the local communities over the implementation of climate change adaptation plans.

As this paper has shown, the local adaptation measures implemented by local community groups are directly and indirectly linked to most of the thematic areas identified in the Climate Change Policy 2019 and NAPA 2010. It suggests that national policies' priorities are reflected in local actions. The majority of the local adaptation measures in the Rajdevi CFUG were applied for landslides control and water scarcity management. Moreover, we found that the local communities are sensitive enough to amend and change the local rules and regulations in order to maintain and enhance social justice and distributional equity in the context of natural resource management and growing climate change impacts at the local level. While the national Climate Change Policy discusses ensuring food security through agricultural interventions, our findings show that the focus on food security is poorly reflected in the local level adaptation plan and actions. We also found that the capacity of the government authority, staff, and stakeholders working on climate change issues is inadequate for effective implementation of the climate change adaptation activities at the local level.

The major challenges of national policy implementation are a lack of coordination and accountability between local government, line ministries, and corresponding thematic offices. Ambiguously defined implementing units at the local level and unclear institutional responsibility throughout the delivery process set the example. Climate change 
policies, rules, and regulations are supposed to be consistent and understandable among its implementers and delivery agents to find a broad acceptance among the population. When the policies cause confusion, the acceptance suffers, leading toward failure. We suggest that only if the real impacted people and appropriate implementing units are identified can the policies and strategies be successful with a broader desirable impact to reduce vulnerability at local level.

The Paris Agreement (PA) within the United Nations Framework Convention on Climate Change (UNFCCC) highlights the need for evaluations and lessons learned from past programs and projects to enhance support for promoting and replicating approaches that are most effective in helping communities to adapt [119]; this paper has analyzed and documented ground experiences and practices to inform better policy design.

Author Contributions: Conceptualization, K.B.D. and P.R.N.; formal analysis, K.B.D., P.R.N. and R.K.S.; investigation, K.B.D.; writing—original draft preparation, K.B.D.; writing-review and editing, all; supervision, P.R.N., and M.K. All authors have read and agreed to the published version of the manuscript.

Funding: Funding was provided by the Hamburg University Cluster of Excellence "Climate, Climate Change and Societies".

Institutional Review Board Statement: Not applicable.

Informed Consent Statement: Informed consent was obtained from all key informants involved in the study.

Data Availability Statement: Not applicable.

Acknowledgments: We gratefully express our gratitude to Rajdevi CFUG of Gorkha and all respondents for contributing to us with their knowledge, experiences, and observations. We are very thankful to experts who shared us with their ideas. We also thank two anonymous reviewers for their valuable feedback, which strengthened our paper.

Conflicts of Interest: The authors declare no conflict of interest.

\section{References}

1. Chaudhary, P.; Aryal, K.P. Global warming in Nepal: Challenges and policy imperatives. J. For. Livelihood 2009, 8, 5-14.

2. Smit, B.; Burton, I.; Klein, R.J.; Wandel, J. An anatomy of adaptation to climate change and variability. In Societal Adaptation to Climate Variability and Change; Springer: Berlin/Heidelberg, Germany, 2000; pp. 223-251.

3. Adger, W.N.; Huq, S.; Brown, K.; Conway, D.; Hulme, M. Adaptation to climate change in the developing world. Prog. Dev. Stud. 2003, 3, 179-195. [CrossRef]

4. Alam, M.; Regmi, B.R. Adverse impacts of climate change on development of Nepal: Integrating adaptation into policies and activities. Bangladesh Cent. Adv. Stud. 2004, 69, 447-451.

5. UNFCCC. United Nations Framework Convention on Climate Change (UNFCCC). Article 2 and Article 11. Text of the Convention. 1992. Available online: http://unfccc.int/essential_background/convention/background/items/1353.php (accessed on 18 February 2017).

6. Schipper, L.; Pelling, M. Disaster risk, climate change and international development: Scope for, and challenges to, integration. Disasters 2006, 30, 19-38. [CrossRef] [PubMed]

7. GoN. National Framework on Local Adaptation Plans for Action; Government of Nepal, Ministry of Forest and Environment (MoFE): Singhdurbar Kathmandu, Nepal, 2019.

8. Rai, J.K.; Gurung, G.B.; Pathak, A. Climate Change Adaptation in MSFP Working Districts: Lessons from LAPA and CAPA Preparation and Implementation in the Koshi Hill Region; ForestAction Nepal and RRN: Kathmandu, Nepal, 2015.

9. Pyakurel, D.; Bista, R.; Ghimire, L. Document Review and Analysis of Community Adaptation Plan of Action and Local Adaptation Plan of Action. Final Report Submitted to Multi-Stakeholder Forestry Programme-Service Support Unit (MSFP-SSU); MSCFP: Kathmandu, Nepal, 2013.

10. GoN. Climate Change Policy, 2019; Government of Nepal, Ministry of Forest and Environment (MoFE): Singhdurbar Kathmandu, Nepal, 2019.

11. Neupane, P.R. Viability Assessment of Jurisdictional Reduced Emissions from Deforestation and Forest Degradation (REDD+) Implementation in Vietnam; Universität Hamburg: Hamburg, Germany, 2015.

12. Neupane, P.R.; Wiati, C.B.; Angi, E.M.; Köhl, M.; Butarbutar, T.; Reonaldus; Gauli, A. How REDD+ and FLEGT-VPA processes are contributing towards SFM in Indonesia-The specialists' viewpoint. Int. For. Rev. 2019, 21, 460-485. [CrossRef] 
13. Harahap, F.; Silveira, S.; Khatiwada, D. Land allocation to meet sectoral goals in Indonesia-An analysis of policy coherence. Land Use Policy 2017, 61, 451-465. [CrossRef]

14. Duraiappah, A.K.; Bhardwaj, A. Measuring Policy Coherence among the MEAs and MDGs; International Institute for Sustainable Development: Winnipeg, MB, Canada, 2007.

15. Nilsson, M.; Zamparutti, T.; Petersen, J.E.; Nykvist, B.; Rudberg, P.; McGuinn, J. Understanding policy coherence: Analytical framework and examples of sector-environment policy interactions in the EU. Environ. Policy Gov. 2012, 22, 395-423. [CrossRef]

16. Curran, P.; Dougill, A.; Pardoe, J.; Vincent, K. Policy brief Policy coherence for sustainable development in sub-Saharan Africa. Target 2018, 17, 1 .

17. UN. General Assembly Takes Action on Second Committee Reports by Adopting 37 Texts. 2016. Available online: https: //www.un.org/press/en/2016/ga11880.doc.htm (accessed on 10 August 2021).

18. UNFCCC. Adoption of the Paris agreement. UN, D.C. \& Framework Convention on Climate Change. 2015. Available online: https:/ / unfccc.int/resource/docs/2015/cop21/eng/10a01.pdf (accessed on 10 August 2021).

19. Pearson, L.; Pelling, M. The UN Sendai framework for disaster risk reduction 2015-2030: Negotiation process and prospects for science and practice. J. Extrem. Events 2015, 2, 1571001. [CrossRef]

20. Howlett, M.; Rayner, J. Design principles for policy mixes: Cohesion and coherence in 'new governance arrangements'. Policy Soc. 2007, 26, 1-18. [CrossRef]

21. Cohen, P.J.; Song, A.M.; Morrison, T.H. Policy coherence with the small-scale fisheries guidelines: Analysing across scales of governance in Pacific small-scale fisheries. In The Small-Scale Fisheries Guidelines; Springer: Berlin/Heidelberg, Germany, 2017; pp. $57-77$.

22. Mallory, T.G. Fisheries subsidies in China: Quantitative and qualitative assessment of policy coherence and effectiveness. Mar. Policy 2016, 68, 74-82. [CrossRef]

23. OECD. Policy Coherence for Sustainable Development 2018: Towards Sustainable and Resilient Societies; OECD Publishing: Paris, France, 2018. [CrossRef]

24. Eldridge, M.; Milner, J.; Williams, J.L. Translating Policy Intent into Action. Available online: https://www.urban.org/ sites/default/files/publication/103199/translating-policy-intent-into-action-a-framework-to-facilitate-implementation-ofagricultural-policies-in-africa_0.pdf (accessed on 23 November 2021).

25. Ranabhat, S.; Ghate, R.; Bhatta, L.D.; Agrawal, N.K.; Tankha, S. Policy coherence and interplay between climate change adaptation policies and the forestry sector in Nepal. Environ. Manag. 2018, 61,968-980. [CrossRef]

26. Gentle, P.; Maraseni, T.N. Climate change, poverty and livelihoods: Adaptation practices by rural mountain communities in Nepal. Environ. Sci. Policy 2012, 21, 24-34. [CrossRef]

27. Dulal, H.B.; Brodnig, G.; Thakur, H.K.; Green-Onoriose, C. Do the poor have what they need to adapt to climate change? A case study of Nepal. Local Environ. 2010, 15, 621-635. [CrossRef]

28. Jones, L.; Boyd, E. Exploring social barriers to adaptation: Insights from Western Nepal. Glob. Environ. Chang. Hum. Policy Dimens. 2011, 21, 1262-1274. [CrossRef]

29. Sapkota, P.; Keenan, R.J.; Ojha, H.R. Community institutions, social marginalization and the adaptive capacity: A case study of a community forestry user group in the Nepal Himalayas. For. Policy Econ. 2018, 92, 55-64. [CrossRef]

30. Maharjan, S.; Sigdel, E.; Sthapit, B.; Regmi, B. Tharu Community's Perception on Climate Changes and Their Adaptive Initiations to Withstand Its Impacts in Western Terai of Nepal. Int. NGO J. 2011, 6, 35-42.

31. Regmi, B.R.; Bhandari, D. Climate change adaptation in Nepal: Exploring ways to overcome the barriers. J. For. Livelihood 2013, 11, 43-61. [CrossRef]

32. Eriksen, S.H.; Nightingale, A.J.; Eakin, H. Reframing adaptation: The political nature of climate change adaptation. Glob. Environ. Chang. Hum. Policy Dimens. 2015, 35, 523-533. [CrossRef]

33. Ojha, H.R.; Ghimire, S.; Pain, A.; Nightingale, A.; Khatri, D.B.; Dhungana, H. Policy without politics: Technocratic control of climate change adaptation policy making in Nepal. Clim. Policy 2016, 16, 415-433. [CrossRef]

34. Silwal, P.; Roberts, L.; Rennie, H.G.; Lexer, M.J. Adapting to climate change: An assessment of local adaptation planning processes in forest-based communities in Nepal. Clim. Dev. 2019, 11, 886-898. [CrossRef]

35. Paudel, N.S.; Ojha, H.; Karki, R.; Gurung, N. Integrating climate change adaptation with local development: Exploring institutional options. J. For. Livelihood 2013, 11, 1-13. [CrossRef]

36. Aryal, K.; Laudari, H.K.; Neupane, P.R.; Maraseni, T. Who shapes the environmental policy in the global south? Unpacking the reality of Nepal. Environ. Sci. Policy 2021, 121, 78-88. [CrossRef]

37. Geerlings, H.; Stead, D. The integration of land use planning, transport and environment in European policy and research. Transport. Policy 2003, 10, 187-196. [CrossRef]

38. Challis, L.; Fuller, S.; Klein, R.; Henwood, M.; Plowden, W.; Webb, A.; Whittingham, P.; Wistow, G. Joint Approaches to Social Policy: Rationality and Practice; Cambridge University Press: New York, NY, USA, 1988.

39. OECD/DAC. DAC Guidelines-Poverty Reduction; OECD Publications: Paris, France, 2001.

40. OECD. Improving Policy Coherence and Integration for Sustainable Development: A Checklist; OECD: Paris, France, 2002.

41. Weston, A.; Pierre-Antoine, D. Poverty and Policy Coherence: A Case Study of Canada's Relations with Developing Countries; NorthSouth Institute: Ottawa, ON, Canada, 2003. 
42. May, P.J.; Jones, B.D.; Beem, B.E.; Neff-Sharum, E.A.; Poague, M.K. Policy coherence and component-driven policymaking: Arctic policy in Canada and the United States. Policy Stud. J. 2005, 33, 37-63. [CrossRef]

43. May, P.J.; Sapotichne, J.; Workman, S. Policy coherence and policy domains. Policy Stud. J. 2006, 34, 381-403. [CrossRef]

44. Dunn, W.N. Public Policy Analysis: An Introduction; Prentice Hall: Upper Saddle River, NJ, USA, 2003.

45. Nilsson, M.; Wiklund, H.; Finnveden, G.; Jonsson, D.K.; Lundberg, K.; Tyskeng, S.; Wallgren, O. Analytical framework and tool kit for SEA follow-up. Environ. Impact Assess. Rev. 2009, 29, 186-199. [CrossRef]

46. Carbone, M. Mission impossible: The European Union and policy coherence for development. Eur. Integr. 2008, 30, 323-342. [CrossRef]

47. Alexander, C.; Bynum, N.; Johnson, E.; King, U.; Mustonen, T.; Neofotis, P.; Oettle, N.; Rosenzweig, C.; Sakakibara, C.; Shadrin, V.; et al. Linking Indigenous and Scientific Knowledge of Climate Change. Bioscience 2011, 61, 477-484. [CrossRef]

48. Hoebink, P. A tale of two countries: Perspectives from the South on the coherence of Eu policies. In Tales of Development: People, Power and Space; Hoebink, P., Slootweg, S., Smith, L., Eds.; Assen: Van Gorcum, The Netherlands, 2008; pp. 187-204.

49. Siitonen, L. Theorising Politics behind Policy Coherence for Development (PCD); Springer: Berlin/Heidelberg, Germany, 2016.

50. Briassoulis, H. Policy integration for complex policy problems: What, why and how. Presented at the 2004 Berlin Conference "Greening of Policies: Interlinkages and Policy Integration", Berlin, Germany, 3-4 December 2004.

51. Meuleman, L. Promoting Policy and Institutional Coherence for the Sustainable Development Goals. Presented at 17th Session of the UN Committee of Experts on Public Administration, New York, NY, USA, 23-27 April 2018. Available online: https: / / digitallibrary.un.org/record/1476289/files/E_C-16_2018_2-EN.pdf (accessed on 17 November 2020).

52. Kivimaa, P.; Mickwitz, P. Making the Climate Count: Climate Policy Integration and Coherence in Finland; Finnish Environment Institute: Helsinki, Finland, 2009.

53. Kalaba, F.K.; Quinn, C.H.; Dougill, A.J. Contribution of forest provisioning ecosystem services to rural livelihoods in the Miombo woodlands of Zambia. Popul. Environ. 2013, 35, 159-182. [CrossRef]

54. Makkonen, M.; Huttunen, S.; Primmer, E.; Repo, A.; Hildén, M. Policy coherence in climate change mitigation: An ecosystem service approach to forests as carbon sinks and bioenergy sources. For. Policy Econ. 2015, 50, 153-162. [CrossRef]

55. Browne, W.P. Studies in government and public policy (USA). In Cultivating Congress: Constituents, Issues, and Interests in Agricultural Policymaking; University Press of Kansas: Lawrence, KS, USA, 1995.

56. Fiske, A.P. Complementarity theory: Why human social capacities evolved to require cultural complements. Personal. Soc. Psychol. Rev. 2000, 4, 76-94. [CrossRef] [PubMed]

57. Ayers, J.; Forsyth, T. Community-Based Adaptation to Climate Change: Strengthening Resilience through Development. Environment 2009, 51, 22-31. [CrossRef]

58. Huq, S.; Reid, H. Community-Based Adaptation: A Vital Approach to the Threat Climate Change Poses to the Poor; International Institute for Environment and Development: London, UK, 2007.

59. Khatri, D.B.; Bista, R.; Gurung, N. Climate change adaptation and local institutions: How to connect community groups with local government for adaptation planning. J. For. Livelihood 2013, 11, 14-28. [CrossRef]

60. IPCC. Climate change 2014: Climate change 2014: Impacts, adaptation, and vulnerability. In Part B: Regional Aspects. Contribution of Working Group II to the Fifth Assessment Report of the Intergovernmental Panel on Climate Change; Barros, V.R., Field, C.B., Dokken, D.J., Mastrandrea, M.D., Mach, K.J., Bilir, T.E., Chatterjee, M., Ebi, K.L., Estrada, Y.O., Genova, R.C., et al., Eds.; IPCC: Geneva, Switzerland, 2014. Available online: https://www.ipcc.ch/site/assets/uploads/2018/02/WGIIAR5-PartB_FINAL.pdf (accessed on 28 June 2018).

61. MoE. National Adaptation Program of Actions; Government of Nepal, Ministry of Environment: Kathmandu, Nepal, 2010.

62. MoE. Climate Change Policy, 2011; Ministry of Environment, Government of Nepal: Kathmandu, Nepal, 2011.

63. Agrawal, A. The Role of Local Institutions in Adaptation to Climate Change; World Bank: Washington, DC, USA, 2008.

64. Sharma, S.K. The political economy of climate change governance in the Himalayan region of Asia: A case study of Nepal. Reg. Environ. Gov. Interdiscip. Perspect. Theor. Issues Comp. Des. 2011, 14, 129-140. [CrossRef]

65. Dixit, A. Ready or Not: Assessing Institutional Aspects of National Capacity for Climate Change Adaptation; World Resources Institute: Washington, DC, USA, 2012.

66. MoITFE. Provincial Adaptation Program of Action (PAPA) to Climate Change (Draft); Ministry of Industry, Tourism, Forest and Environment, Gandaki Province: Pokhara, Nepal, 2019.

67. MoE. Local Adaptation Plan of Action (LAPA) Framework; Ministry of Environment, Government of Nepal: Kathmandu, Nepal, 2011.

68. Rupantaran Nepal. Consolidating Learning of Local and Community Based Adaptation Planning: Implications for Adaptation Policy and Practice. Available online: http://rupantaran.org.np/wp-content/uploads/2015/12/Consolidating-learningof-local-and-community-based-adaptation-planning-Implications-for-Adaptation-Policy-and-Practice.pdf (accessed on 23 November 2021).

69. Jamarkattel, B.K. Institutional Mechanism for Intervention on Climate Change Adaptation at the Local Level. Master's Thesis, Tribhuvan University, Institute of Forestry, Pokhara, Nepal, 2014.

70. GoN. The Guideline for Community Forestry Development Programme; Forest Department, C.F.D., Ed.; Government of Nepal, Ministry of Forest and Soil Conservation (MoFSC): Babarmahal Kathmandu, Nepal, 2014. 
71. Ayers, J. Understanding the Adaptation Paradox: Can Global Climate Change Adaptation Policy be Locally Inclusive? The London School of Economics and Political Science: London, UK, 2010.

72. Helvetas, N. Nepal's climate change polices and plans: Local communities' perspective. Environ. Clim. Ser. 2011, 1, 1-14.

73. McLaughlin, M.W. Learning from experience: Lessons from policy implementation. Educ. Eval. Policy Anal. 1987, 9, 171-178. [CrossRef]

74. GoN. The Environment Protection Act, 2019; Government of Nepal, Ministry of Forest and Environment (MoFE): Singhdurbar Kathmandu, Nepal, 2019.

75. GoN. Local Government Operation Act, 2017; Government of Nepal, Ministry of Federal Affairs and General Administration: Kathmandu, Nepal, 2017.

76. GoN. Forest Act 2019; Government of Nepal, Ministry of Forest and Environment (MoFE): Singhdurbar Kathmandu, Nepal, 2019.

77. Tiwari, K.R.; Rayamajhi, S.; Pokharel, R.K.; Balla, M.K. Does Nepal's Climate Change Adaption Policy and Practices Address Poor and Vulnerable Communities. JL Pol'y Glob. 2014, 23, 28.

78. Reid, H.; Huq, S. Mainstreaming community-based adaptation into national and local planning introduction. Clim. Dev. 2014, 6, 291-292. [CrossRef]

79. England, M.I.; Dougill, A.J.; Stringer, L.C.; Vincent, K.E.; Pardoe, J.; Kalaba, F.K.; Mkwambisi, D.D.; Namaganda, E.; Afionis, S. Climate change adaptation and cross-sectoral policy coherence in southern Africa. Reg. Environ. Chang. 2018, 18, 2059-2071. [CrossRef]

80. Fernández-Blanco, C.R.; Burns, S.L.; Giessen, L. Mapping the fragmentation of the international forest regime complex: Institutional elements, conflicts and synergies. Int. Environ. Agreem. Politics Law Econ. 2019, 19, 187-205. [CrossRef]

81. Bunce, M.; Brown, K.; Rosendo, S. Policy misfits, climate change and cross-scale vulnerability in coastal Africa: How development projects undermine resilience. Environ. Sci. Policy 2010, 13, 485-497. [CrossRef]

82. Agrawal, A.; Perrin, N.; Chhatre, A.; Benson, C.; Cononen, M. Climate Policy Processes, Local Institutions and Adaptation Actions: Mechanisms of Translations and Influence. Social Development Paper 119; The World Bank: Washington, DC, USA, 2009.

83. Darjee, K.B.; Ankomah, G.O. Climate Change Adaptation Practices of Forest Dependent Poor People: Comparative Study of Nepal and Ghana. In Proceedings of the Science Policy Gap Regarding Informed Decisions in Forest Policy and Management. What Scientific Information Are Policy Makers Really Interested in?: Proceedings of the 6th International DAAD Workshop, Santiago, Chile, 12-20 November 2016.

84. Pokharel, B.K.; Branney, P.; Nurse, M.; Malla, Y.B. Community forestry: Conserving forests, sustaining livelihoods and strengthening democracy. J. For. Livelihood 2007, 6, 8-19.

85. CBS. National Climate Change Impact Survey 2016. A Statistical Report; Central Bureau of Statistics: Kathmandu, Nepal, 2017.

86. GoN. Nepal Disaster Report; Ministry of Home Affairs (MoHA) and Disaster Preparedness Network-Nepal (DPNet-Nepal): Kathmandu Nepal, 2015.

87. Nightingale, A.J. A socionature approach to adaptation: Political transition, intersectionality, and climate change programmes in Nepal. In Climate Change Adaptation and Development; Routledge: London, UK, 2014; pp. 235-250.

88. Eriksen, S.; Brown, K. Sustainable Adaptation to Climate Change; Taylor \& Francis Group: Oxfordshire, UK, 2011.

89. Matias, D.M. Local Adaptation to Climate Change: A Case Study Among the Indigenous Palaw'ans in the Philippines. In Climate Change in the Asia-Pacific Region; Springer: Berlin/Heidelberg, Germany, 2015; pp. 173-187.

90. Laidler, G.J. Inuit and Scientific Perspectives on the Relationship Between Sea Ice and Climate Change: The Ideal Complement? Clim. Chang. 2006, 78, 407-444. [CrossRef]

91. Agrawal, A.; Perrin, N. Climate adaptation, local institutions and rural livelihoods. Adapt. Clim. Chang. Threshold. Values Gov. 2009, 350-367. Available online: https:/ /www.google.com/books?hl=en\&lr=\&id=dsD5UdpEOPsC\&oi=fnd\&pg=PA350 $\& \mathrm{dq}=$ Climate+adaptation, +local+institutions+and+rural+livelihoods\&ots=4zh_smhkqS\&sig=vOrbL8s44o9jFt_7j8STkzusSxU (accessed on 22 November 2021).

92. Amaru, S.; Chhetri, N.B. Climate adaptation: Institutional response to environmental constraints, and the need for increased flexibility, participation, and integration of approaches. Appl. Geogr. 2013, 39, 128-139. [CrossRef]

93. Rodima-Taylor, D.; Olwig, M.F.; Chhetri, N. Adaptation as innovation, innovation as adaptation: An institutional approach to climate change. Appl. Geogr. 2012, 33, 107-111. [CrossRef]

94. Regmi, B.R.; Star, C.; Leal, W. Effectiveness of the Local Adaptation Plan of Action to support climate change adaptation in Nepal. Mitig. Adapt. Strateg. Glob. Chang. 2016, 21, 461-478. [CrossRef]

95. Neupane, P.; Gauli, A.; Mundhenk, P.; Köhl, M. Developing indicators for participatory forest biodiversity monitoring systems in South Sumatra. Int. For. Rev. 2020, 22, 464-484. [CrossRef]

96. Ribot, J. Vulnerability does not just fall from the sky: Toward multi-scale pro-poor climate policy. In Handbook on Climate Change and Human Security; Edward Elgar Publishing: Washington, DC, USA, 2013.

97. Gentle, P.; Thwaites, R.; Race, D.; Alexander, K. Differential impacts of climate change on communities in the middle hills region of Nepal. Nat. Hazards 2014, 74, 815-836. [CrossRef]

98. Jamarkattel, B.K.; Dhakal, S.; Joshi, J.; Gautam, D.R.; Hamal, S.S. Responding to Differential Impacts: Lessons from Hariyo Ban Program in Nepal; CARE Nepal: Dhobighat Nepal, 2019.

99. Ayers, J.M.; Huq, S. The value of linking mitigation and adaptation: A case study of Bangladesh. Environ. Manag. 2009, 43, 753-764. [CrossRef] [PubMed] 
100. Ministry of Forests and Environment. Nepal's National Adaptation Plan (NAP) Process: Reflecting on Lessons Learned and the Way Forward. The NAP Global Network, Action on Climate Today (ACT) and Practical Action Nepal; Government of Nepal: Kathmandu, Nepal, 2018.

101. Bishokarma, N.K. Capacity Gaps and Needs Analysis Report: Livelihoods and Governance Sector; Climate Change Management Division, National Adaptation Plan Formulation Process: Kathmandu, Nepal, 2017.

102. The Food and Agriculture Organization. An Introduction to the Basic Concepts of Food Security. Food Security Information for Action. Practical Guides; The Food and Agriculture Organization: Rome, Italy, 2008.

103. Edame, G.; Anam, B.E.; Fonta, W.; Duru, E. Climate Change, Food Security and Agricultural Productivity in Africa: Issues and Policy Directions. Int. J. Humanit. Soc. Sci. 2011, 1, 205-223.

104. FAO. Declaration of the World Summit on Food Security. Available online: https://www.fao.org/3/k6050e/k6050e.pdf (accessed on 23 November 2021).

105. Ochieng, J.; Kirimi, L.; Mathenge, M. Effects of climate variability and change on agricultural production: The case of small scale farmers in Kenya. NJAS-Wagening. J. Life Sci. 2016, 77, 71-78. [CrossRef]

106. Kichamu, E.A.; Ziro, J.S.; Palaniappan, G.; Ross, H. Climate change perceptions and adaptations of smallholder farmers in Eastern Kenya. Environ. Dev. Sustain. 2018, 20, 2663-2680. [CrossRef]

107. Aryal, J.P.; Sapkota, T.B.; Khurana, R.; Khatri-Chhetri, A.; Rahut, D.B.; Jat, M.L. Climate change and agriculture in South Asia: Adaptation options in smallholder production systems. Environ. Dev. Sustain. 2020, 22, 5045-5075. [CrossRef]

108. Lin, B.B. Resilience in agriculture through crop diversification: Adaptive management for environmental change. BioScience 2011, 61, 183-193. [CrossRef]

109. Georgopoulou, E.; Mirasgedis, S.; Sarafidis, Y.; Vitaliotou, M.; Lalas, D.; Theloudis, I.; Giannoulaki, K.-D.; Dimopoulos, D.; Zavras, V. Climate change impacts and adaptation options for the Greek agriculture in 2021-2050: A monetary assessment. Clim. Risk Manag. 2017, 16, 164-182. [CrossRef]

110. Bird, N. The Future for Climate Finance in Nepal. Report for CDDE Bangkok; Overseas Development Insitutte (ODI): London, UK, 2011.

111. Wiggins, S. Adaptation United: Building Blocks from Developing Countries on Integrated Adaptation; Tearfund: London, UK, 2011.

112. Dongol, Y.; Heinen, J.T. Pitfalls of CITES implementation in Nepal: A policy gap analysis. Environ. Manag. 2012, 50, 181-190. [CrossRef]

113. Ostrom, E. Governing the Commons: The Evolution of Institutions for Collective Action; Cambridge University Press: New York, NY, USA, 1990.

114. Beck, S.; Borie, M.; Chilvers, J.; Esguerra, A.; Heubach, K.; Hulme, M.; Lidskog, R.; Lövbrand, E.; Marquard, E.; Miller, C. Towards a reflexive turn in the governance of global environmental expertise. The cases of the IPCC and the IPBES. GAIA-Ecol. Perspect. Sci. Soc. 2014, 23, 80-87. [CrossRef]

115. Hulme, M. Problems with making and governing global kinds of knowledge. Glob. Environ. Chang. 2010, 20, 558-564. [CrossRef]

116. Berkhout, J.; Beyers, J.; Braun, C.; Hanegraaff, M.; Lowery, D. Making inference across mobilisation and influence research: Comparing top-down and bottom-up mapping of interest systems. Political Stud. 2018, 66, 43-62. [CrossRef] [PubMed]

117. Berkhout, J.; Lowery, D. Short-term volatility in the EU interest community. J. Eur. Public Policy 2011, 18, 1-16. [CrossRef]

118. Sanders, A.J.; da Silva Hyldmo, H.; Ford, R.M.; Larson, A.M.; Keenan, R.J. Guinea pig or pioneer: Translating global environmental objectives through to local actions in Central Kalimantan, Indonesia's REDD+ pilot province. Glob. Environ. Chang. 2017, 42, 68-81. [CrossRef]

119. Uddin, M.N.; Bokelmann, W.; Dunn, E.S. Determinants of Farmers' Perception of Climate Change: A Case Study from the Coastal Region of Bangladesh. Am. J. Clim. Chang. 2017, 6, 151-165. [CrossRef] 